\title{
CRÓNICA DE JURISPRUDENCIA DEL TRIBUNAL DE JUSTICIA DE LA UNIÓN EUROPEA, ENERO-ABRIL 2019
}

\author{
FERNANDO CASTILLO DE LA TORRE \\ Servicio Jurídico de la Unión Europea \\ fernando.castillo-de-la-torre@ec.europa.eu
}

PETRA NEMECKOVA ${ }^{1}$

Servicio Jurídico de la Unión Europea

petra.Nemeckova@ec.europa.eu

I. INSTITUCIONES, PRINCIPIOS Y DERECHOS FUNDAMENTALES. II. MERCADO INTERIOR, LIBRE CIRCULACIÓN Y CIUDADANIIA EUROPEA. III. AGRICULTURA. IV. DERECHO DE LA COMPETENCIA. V. APROXIMACIÓN DE LEGISLACIONES. VI. UNION ECONÓMICA Y MONETARIA. VII. MEDIO AMBIENTE. VIII. JUSTICIA, LIBERTAD Y SEGURIDAD. IX. RELACIONES EXTERIORES.

1 Miembros del Servicio Jurídico de la Unión Europea. 


\section{INSTITUCIONES, PRINCIPIOS Y DERECHOS FUNDAMENTALES}

En la ponderación del derecho a la intimidad y la libertad de expresión, la grabación en vídeo de policías en una comisaría durante una toma de declaración y la publicación del vídeo grabado en Youtube pueden constituir un tratamiento de datos personales con fines exclusivamente periodísticos, siempre que las citadas grabación y publicación tengan como única finalidad la divulgación al público de información, opiniones o ideas (Sentencia de 14 de febrero de 2019, Buivids, C-345/17, EU:C:2019:122).

Esta sentencia da respuesta a una petición de decisión prejudicial presentada en el contexto de un litigio entre el Sr. Buivids y la Agencia Estatal de Protección de Datos de Letonia, en relación con un recurso para que se declarara la ilegalidad de una resolución de esa agencia según la cual el Sr. Buivids había infringido la legislación nacional al publicar en el sitio web www.youtube.com un vídeo, grabado por él mismo, de su declaración en las dependencias de una comisaría de la Policía Nacional en el marco de un expediente administrativo sancionador.

La agencia letona resolvió que el Sr. Buivids estaba obligado a proporcionar a los policías, en su condición de interesados, la información relativa a la finalidad del tratamiento de sus datos personales, y a la agencia, información sobre la finalidad de la grabación del vídeo controvertido y su publicación en un sitio de internet que acreditase que el objetivo previsto era acorde con lo dispuesto en la ley de protección de datos nacional. Por consiguiente, la Agencia Estatal de Protección de Datos requirió al Sr. Buivids para que hiciera lo necesario con el fin de que este vídeo se suprimiera del sitio de internet www.youtube.com y de otros sitios. Ante los tribunales nacionales, el Sr. Buivids alegó, en particular, que el vídeo controvertido mostraba a funcionarios de la Policía Nacional, es decir, personas públicas en un lugar accesible al público, que no están comprendidas, como tales, en el ámbito de aplicación personal de la ley de protección de datos.

La petición de decisión prejudicial tenía pues por objeto la interpretación de la Directiva 95/46/CE del Parlamento Europeo y del Consejo, relativa a la protección de las personas físicas en lo que respecta al tratamiento de datos personales y a la libre circulación de estos datos, y en particular de su art. 9, en virtud del cual, en lo referente al tratamiento de datos personales con fines exclusivamente periodísticos o de expresión artística o literaria, los Estados miembros pueden establecer exenciones y excepciones solo en la medida en que resulten necesarias para conciliar el derecho a la intimidad con las normas que rigen la libertad de expresión. 
El Tribunal de Justicia declaró, en primer lugar, que la grabación en vídeo de policías en una comisaría, durante una toma de declaración, y la publicación del vídeo grabado en un sitio de internet de vídeos en el que los usuarios pueden enviarlos, verlos y compartirlos están comprendidas en el ámbito de aplicación de esta directiva.

En segundo lugar, recordó que el objetivo de la directiva es que los Estados miembros, al tiempo que permiten la libre circulación de datos personales, garanticen la protección de las libertades y de los derechos fundamentales de las personas físicas, y, en particular, del derecho a la intimidad, en lo que respecta al tratamiento de dichos datos. Sin embargo, dicho objetivo no puede alcanzarse sin tener en cuenta que los referidos derechos fundamentales han de conciliarse, en una cierta medida, con el derecho fundamental a la libertad de expresión, lo que tiene por objeto precisamente el art. 9. De este modo, las exenciones y excepciones previstas en el art. 9 de la directiva se aplican no solo a las empresas de medios de comunicación, sino también a toda persona que ejerza una actividad periodística. El Tribunal de Justicia recordó, al respecto, que las «actividades periodísticas» son las que tienen por finalidad divulgar al público información, opiniones o ideas, por cualquier medio de transmisión.

No obstante, el Tribunal de Justicia admitió que no puede considerarse que cualquier información publicada en internet, relativa a datos personales, esté comprendida en el concepto de «actividades periodísticas» y disfrute por ello de las exenciones y excepciones previstas en el art. 9 de la directiva. De este modo, el tribunal remitente deberá comprobar si se desprende del vídeo controvertido que su grabación y su publicación tenían como única finalidad la divulgación al público de información, opiniones o ideas. Por añadidura, para obtener una ponderación equilibrada del derecho a la intimidad y a la libertad de expresión, la protección del primero exige que las excepciones y restricciones a la protección de los datos se establezcan dentro de los límites de lo que resulte estrictamente necesario. Apoyándose en la jurisprudencia del Tribunal Europeo de Derechos Humanos sobre dicho equilibrio, el Tribunal de Justicia concluyó que no se puede excluir que la grabación y la publicación del vídeo controvertido, que se efectuaron sin informar a los interesados de la realización de esa grabación y de su finalidad, constituya una injerencia en el derecho fundamental al respeto de la intimidad de estas personas, es decir, los policías que figuran en dicho vídeo.

Cuando la Comisión recibe una solicitud de registro de una propuesta de iniciativa ciudadana europea, no le corresponde, en el momento del registro, comprobar si se aporta la prueba de todos los elementos de hecho invocados ni si la motivación que subyace a la propuesta y a las medidas que se proponen es suficiente, sino que debe limitarse a examinar 


\section{si, desde un punto de vista objetivo, las medidas previstas en abstrac- to podrían adoptarse sobre la base de los tratados (Sentencia de 7 de marzo de 2019, Izsák y Dabis/Comisión, C-420/16 P, EU:C:2019:177).}

Este asunto trata de una iniciativa ciudadana europea presentada por los Sres. Izsák y Dabis, junto con otras cinco personas, en junio de 2013 a la Comisión sobre una propuesta de iniciativa ciudadana denominada «Política de cohesión para la igualdad de las regiones y la preservación de las culturas regionales». Esta iniciativa pretendía que la política de cohesión de la Unión preste especial atención a las zonas geográficas cuyas características étnicas, culturales, religiosas o lingüísticas difieran de aquellas de las zonas circundantes (las llamadas «regiones con una minoría nacional»). De este modo, la finalidad principal de la iniciativa era permitir que las regiones con una minoría nacional tengan acceso, mediante medidas de apoyo, preservación o desarrollo, a las ventajas derivadas de dicha política, con el fin de impedir que resulten económicamente desfavorecidas con respecto a las regiones circundantes.

Antes de poder empezar a recoger el número necesario de firmas, los organizadores de una iniciativa ciudadana europea deben presentarla para su registro ante la Comisión, la cual examina en especial su objeto y sus objetivos. La Comisión puede denegar el registro de la iniciativa, en particular cuando el objeto de esta exceda manifiestamente de sus competencias. La Comisión denegó el registro de la iniciativa por considerar que estaba manifiestamente fuera del ámbito de sus competencias para proponer un acto jurídico al legislador de la Unión. Los Sres. Izsák y Dabis interpusieron entonces ante el Tribunal General un recurso de anulación de la decisión de la Comisión que fue desestimado por el Tribunal General, que fundamentó su resolución, en particular, en que los organizadores no habían demostrado la existencia de la amenaza y de la desventaja mencionadas.

En un procedimiento de recurso de casación, el Tribunal de Justicia anuló la sentencia del Tribunal General y la decisión de la Comisión. Recordando que el objetivo de la iniciativa ciudadana europea consiste en fomentar la participación de los ciudadanos y en hacer que la Unión sea más accesible, de manera que debe garantizarse a aquellos un fácil acceso a este instrumento, el Tribunal de Justicia declaró que, para poder registrar una iniciativa ciudadana europea, no debe realizarse, en esta fase, una apreciación de los hechos y de los elementos de prueba. Precisamente la cuestión de si la medida propuesta está comprendida en el ámbito de competencias de la Comisión no constituye una cuestión de hecho o de apreciación de las pruebas sujeta a las normas en materia de carga de la prueba, sino sobre todo una cuestión de interpretación y aplicación de las disposiciones de los tratados. Así pues, cuando 
la Comisión recibe una solicitud de registro de una propuesta de iniciativa ciudadana, no le corresponde, en ese momento, comprobar si se aporta la prueba de todos los elementos de hecho invocados ni si la motivación que subyace a la propuesta y a las medidas que se proponen es suficiente. Debe limitarse a examinar si, desde un punto de vista objetivo, las medidas previstas en abstracto podrían adoptarse sobre la base de los tratados.

Conviene señalar que, no obstante, el Tribunal confirmó la declaración del Tribunal General según la cual las características étnicas, culturales, religiosas o lingüísticas específicas de las regiones con una minoría nacional no están comprendidas en el concepto de «desventaja demográfica grave y permanente» $y$, por tanto, no pueden tenerse en consideración en virtud de este concepto a los efectos de la política de cohesión. En efecto, estas características no suponen sistemáticamente una desventaja para el desarrollo económico con respecto a las regiones circundantes.

El Tribunal de Justicia recapitula sobre el principio de abuso de derecho, y sus condiciones de aplicación, en el ámbito fiscal, y considera que habida cuenta del principio general del derecho de la Unión de prohibición de las prácticas abusivas y de la necesidad de imponer el respeto de este principio en la aplicación del derecho de la Unión, la falta de disposiciones nacionales o contractuales destinadas a combatir tales prácticas es irrelevante en relación con la obligación de las autoridades nacionales de denegar el amparo de los derechos establecidos por una directiva cuando sean invocados de manera fraudulenta o abusiva (Sentencia de 26 de febrero de 2019, N Luxembourg y otros, C-115/16, C-118/16, C-119/16 y C-299/16, EU:C:2019:134).

Esta sentencia supone una recapitulación, por la Gran Sala, de los principios relativos al abuso de derecho en el derecho de la Unión. Las peticiones de decisión prejudicial tenían por objeto la interpretación de la Directiva 2003/49/CE del Consejo, relativa a un régimen fiscal común aplicable a los pagos de intereses y cánones efectuados entre sociedades asociadas de diferentes Estados miembros, así como de los arts. 49 TFUE, 54 TFUE y 63 TFUE. Dichas peticiones se presentaron en el contexto de sendos litigios entre N Luxembourg 1, X Denmark A/S, C Danmark I y Z Denmark ApS y el Skatteministeriet (Ministerio de Hacienda, Dinamarca), en relación con la obligación impuesta a las citadas sociedades de liquidar un impuesto retenido en la fuente con motivo del pago de intereses efectuado por ellas a sociedades no residentes respecto de las que la autoridad fiscal considera que no son los beneficiarios efectivos de dichos intereses y no pueden, por tanto, acogerse a la exención de cualquier impuesto establecida por la Directiva 2003/49. 
En los cuatro litigios principales, una sociedad luxemburguesa que se subrogó en las obligaciones de una sociedad danesa (Asunto C-115/16) y tres sociedades danesas (asuntos C-118/16, C-119/16 y C-299/16) impugnaban las resoluciones de la SKAT (Administración Tributaria, Dinamarca) por las que se les denegó la exención del impuesto sobre sociedades establecida en la Directiva 2003/49 respecto de los intereses satisfechos a entidades residentes en otro Estado miembro, con motivo de que dichas sociedades no eran los beneficiarios efectivos de tales intereses y constituían meras sociedades instrumentales. Para poder acogerse a las ventajas fiscales establecidas por la Directiva 2003/49, la entidad que percibe los intereses debe cumplir los requisitos que se enuncian en esa directiva. No obstante, puede darse el caso de grupos de sociedades que no reúnen dichos requisitos pero que intercalan, entre la sociedad pagadora de los intereses y la que va a disponer de ellos efectivamente, una o varias sociedades artificiales que cumplen los requisitos formales de aquella directiva. Las cuestiones planteadas por los órganos jurisdiccionales remitentes sobre el abuso de derecho y el concepto de «beneficiario efectivo» se suscitaron en relación con tales construcciones financieras.

Las cuestiones prejudiciales formuladas por los órganos jurisdiccionales nacionales planteaban tres temáticas. La primera se refería al concepto de «beneficiario efectivo» en el sentido de la Directiva 2003/49, así como a la existencia de una base jurídica que permita a un Estado miembro denegar, con motivo de la comisión de un abuso de derecho, la exención de cualquier impuesto establecida en el art. 1, apdo. 1, de la citada directiva a una sociedad que ha pagado intereses a una entidad residente en otro Estado miembro. Partiendo del supuesto de que existe tal base jurídica, la segunda temática abordada por las cuestiones prejudiciales se refería a los elementos constitutivos de un eventual abuso de derecho y a las maneras de probar tal abuso. Finalmente, la tercera temática que planteaban las cuestiones, igualmente en la hipótesis de que un Estado tenga la posibilidad de denegar a tal sociedad las ventajas de la Directiva 2003/49, versaba sobre la interpretación de las disposiciones del TFUE relativas a la libertad de establecimiento y a la libre circulación de capitales, con el fin de permitir a los órganos jurisdiccionales remitentes verificar si la legislación danesa viola las mencionadas libertades.

Los órganos jurisdiccionales remitentes solicitaban que se dilucide si, para combatir un abuso de derecho en el marco de la aplicación de la Directiva 2003/49, un Estado miembro debe haber adoptado una disposición nacional específica de transposición de esta directiva o puede referirse a principios o a disposiciones nacionales o contractuales contra las prácticas abusivas. A este respecto, según reiterada jurisprudencia, existe en el ordenamiento jurídico de la Unión un principio general del derecho que establece que los justiciables no pueden invocar el derecho de la Unión de forma abusiva o fraudulenta. Los 
justiciables están obligados a respetar este principio general del derecho. En efecto, la aplicación de la normativa de la Unión no puede extenderse hasta llegar a cubrir las operaciones que se realicen para beneficiarse fraudulenta o abusivamente de las ventajas establecidas en el derecho de la Unión. De esta manera, el referido principio implica que un Estado miembro debe denegar el amparo de las disposiciones del derecho de la Unión cuando se invoquen no para la realización de los objetivos de las disposiciones en cuestión, sino con el fin de disfrutar de una ventaja del derecho de la Unión aunque los requisitos establecidos al respecto se cumplan solo formalmente.

De igual forma, si bien el art. 5, apdo. 2, de la Directiva 2003/49 dispone que los Estados miembros podrán, en caso de fraude, evasión o abuso, denegar el amparo de esta directiva o negarse a aplicarla, no puede interpretarse esta disposición en el sentido de que excluye la aplicación del principio general del derecho de la Unión de prohibición de las prácticas abusivas, por cuanto la aplicación del referido principio no está sometida a una exigencia de transposición como la que rige para las disposiciones de la citada directiva.

Por otra parte, no cabe oponer a la aplicación del principio general de prohibición de las prácticas abusivas el derecho de los contribuyentes a obtener ventajas de la competencia ejercida por los Estados miembros con motivo de la falta de armonización de la tributación de los beneficios. A este respecto, si bien el intento de un contribuyente de acogerse al régimen fiscal que le resulte más ventajoso no puede fundar, como tal, una presunción general de fraude o de abuso, también es cierto que tal contribuyente no puede disfrutar de un derecho o de una ventaja que se deriven del derecho de la Unión si la operación en cuestión es puramente artificial desde el punto de vista económico y persigue eludir la aplicación de la legislación del Estado miembro de que se trate.

Por ello, incumbe a las autoridades y a los órganos jurisdiccionales nacionales denegar el amparo de los derechos establecidos por la Directiva 2003/49 cuando estos se invocan de manera fraudulenta o abusiva. De este modo, habida cuenta del principio general del derecho de la Unión de prohibición de las prácticas abusivas y de la necesidad de imponer el respeto de este principio en la aplicación del derecho de la Unión, la falta de disposiciones nacionales o contractuales destinadas a combatir tales prácticas es irrelevante en relación con la obligación de las autoridades nacionales de denegar el amparo de los derechos establecidos por la Directiva 2003/49 cuando sean invocados de manera fraudulenta o abusiva.

En la medida en que unos hechos abusivos o fraudulentos no pueden fundamentar un derecho previsto en el ordenamiento jurídico de la Unión, la denegación de una ventaja derivada de una directiva, en este caso, de la Directiva 2003/49, no equivale a imponer una obligación al particular 
afectado en virtud de dicha directiva, sino que solo es la mera consecuencia de la constatación de que las condiciones objetivas requeridas para la obtención de la ventaja buscada, establecidas en la citada directiva por lo que se refiere a dicho derecho, se cumplen solo formalmente.

Por todas estas consideraciones, responde que el art. 1, apdo. 1, de la Directiva 2003/49, en relación con el art. 1, apdo. 4, de esta directiva, debe interpretarse en el sentido de que la exención de cualquier impuesto sobre los pagos de intereses que se establece en aquel apartado está reservada exclusivamente a los beneficiarios efectivos de tales intereses, a saber, las entidades que disfrutan realmente de los intereses en cuestión desde el punto de vista económico y que, por lo tanto, disponen de la facultad de decidir libremente el destino de estos.

El principio general del derecho de la Unión según el cual los justiciables no pueden invocar normas del derecho de la Unión de manera fraudulenta o abusiva debe interpretarse en el sentido de que las autoridades y los órganos jurisdiccionales nacionales, cuando se produzca una práctica fraudulenta o abusiva, deben denegar al contribuyente el beneficio de la exención de cualquier impuesto sobre los pagos de intereses establecida en el art. 1, apdo. 1, de la Directiva 2003/49, aun cuando no exista disposición nacional o contractual alguna que contemple tal denegación.

Para probar que existe una práctica abusiva, es necesario que concurran, por un lado, una serie de circunstancias objetivas de las que resulte que, a pesar de que se han respetado formalmente las condiciones previstas por la normativa de la Unión, no se ha alcanzado el objetivo perseguido por dicha normativa, y, por otro lado, un elemento subjetivo que consiste en la voluntad de obtener un beneficio resultante de la normativa de la Unión mediante la creación artificiosa de las condiciones exigidas para su obtención. La concurrencia de cierto número de indicios puede acreditar la existencia de un abuso de derecho, siempre que esos indicios sean objetivos y concordantes. Tales indicios pueden consistir, en particular, en la existencia de sociedades instrumentales carentes de justificación económica, así como en el carácter puramente formal de la estructura del grupo de sociedades, de las operaciones financieras y de los préstamos.

La circunstancia de que el Estado miembro del que proceden los intereses haya celebrado un convenio con el Estado tercero en el que reside la sociedad beneficiaria efectiva de dichos intereses es irrelevante a la hora de constatar, en su caso, un abuso de derecho.

A efectos de la denegación del reconocimiento a una sociedad de la condición de beneficiario efectivo de los intereses o de la constatación de la existencia de un abuso de derecho, una autoridad nacional no está obligada 
a identificar la entidad o las entidades a las que considera beneficiarios efectivos de esos intereses.

La directiva relativa al establecimiento de un marco general para la igualdad de trato en el empleo y la ocupación obliga al órgano jurisdiccional nacional a reexaminar, para el periodo posterior al fin del plazo de transposición de dicha directiva, la reducción del importe de la pensión resultado de la sanción disciplinaria firme por la que se ordenó la jubilación forzosa anticipada del funcionario afectado, con el fin de determinar el importe que habría percibido de no haber existido discriminación por motivos de orientación sexual (Sentencia de 15 de enero de 2019, E.B. , C-258/17, EU:C:2019:17).

La petición de decisión prejudicial tenía por objeto la interpretación del art. 2 de la Directiva 2000/78/CE del Consejo, relativa al establecimiento de un marco general para la igualdad de trato en el empleo y la ocupación. La petición se había presentado en el contexto de un litigio entre E. B. y la Versicherungsanstalt öffentlich Bediensteter BVA (Caja del Seguro por Enfermedad de los Funcionarios y Agentes del Estado, Austria), en relación con la legalidad y los efectos de la resolución disciplinaria impuesta a E. B. en 1975 por tentativa de abusos deshonestos sobre menores de sexo masculino.

Mediante su primera cuestión prejudicial, el órgano jurisdiccional remitente preguntaba, en esencia, si el art. 2 de la Directiva 2000/78 debe interpretarse en el sentido de que se aplica a los efectos jurídicos de una resolución disciplinaria firme adoptada antes de la entrada en vigor de esta directiva, por la que se ordenó la jubilación forzosa anticipada de un funcionario con una reducción del importe de su pensión.

El Tribunal examina primero si una situación como la creada por la resolución disciplinaria de 1975 está comprendida en el ámbito de aplicación ratione materiae de la Directiva 2000/78. Concluye que siempre que la pensión abonada a E. B. esté incluida en el concepto de «retribución» en el sentido del art. 157 TFUE, y, por consiguiente, de la Directiva 2000/78, una situación como la creada por la resolución disciplinaria de 1975 está comprendida en el ámbito de aplicación ratione materiae de esta directiva.

En segundo lugar, examina si tal situación está comprendida en el ámbito de aplicación ratione temporis de dicha directiva. En el caso de autos, señala que la resolución disciplinaria de 1975 dio lugar a una situación jurídica definitivamente consolidada antes de la aplicación de la Directiva 2000/78. Por lo tanto, a falta de disposiciones particulares en este sentido en la Directiva 2000/78, una resolución como la controvertida en el litigio principal no puede incluirse en el ámbito de aplicación del derecho de la Unión en lo que 
atañe al periodo anterior a la expiración del plazo de transposición de dicha directiva. Tan solo después de finalizado el plazo de transposición de la Directiva 2000/78, a saber, a partir del 3 de diciembre de 2003, esta hizo entrar en el ámbito de aplicación del derecho de la Unión los efectos de la resolución controvertida en el litigio principal.

Aunque el Estado austriaco comenzó a abonar periódicamente a E. B. una pensión de jubilación a partir del año 1976, con arreglo a la resolución disciplinaria de 10 de junio de 1975, continuó pagando esta pensión con posterioridad a la expiración del plazo de transposición de la Directiva 2000/78. Por ende, dado que se continuó pagando la pensión a E. B., esta resolución, si bien adquirió firmeza antes de la expiración del plazo de transposición de la Directiva 2000/78, no agotó todos sus efectos jurídicos antes de la expiración de ese plazo, sino que, por el contrario, ha seguido produciendo efectos periódicamente durante toda la duración de la jubilación del interesado, después de dicha expiración. Por consiguiente, la situación creada por la resolución disciplinaria de 1975 constituye una situación nacida antes de la entrada en vigor de la Directiva 2000/78, pero cuyos efectos futuros se rigen por esta Directiva a partir de la expiración del plazo de transposición de esta, con arreglo al principio según el cual las nuevas normas se aplican de inmediato a tales efectos futuros.

En cuanto al fondo, el Tribunal de Justicia interpreta la Directiva 2000/78 en el sentido de que, en una situación como la descrita, obliga al órgano jurisdiccional nacional a reexaminar, para el periodo que comenzó el 3 de diciembre de 2003, no la sanción disciplinaria firme por la que se ordenó la jubilación forzosa anticipada del funcionario afectado, sino la reducción del importe de su pensión, con el fin de determinar el importe que habría percibido de no haber existido discriminación por motivos de orientación sexual.

\section{MERCADO INTERIOR, LIBRE CIRCULACIÓN Y CIUDADANÍA EUROPEA}

Un criterio de pérdida de la ciudadanía de un Estado miembro, y, por tanto, de la Unión, que se fundamenta en la residencia habitual de los nacionales en dicho Estado miembro durante un periodo ininterrumpido de diez años fuera de la Unión Europea, puede considerarse legítimo porque refleja la inexistencia del mencionado vínculo efectivo; no obstante, se requiere un examen individual de las consecuencias que tal pérdida tendría para las personas afectadas desde el punto de vista del derecho de la Unión (Sentencia de 12 de marzo de 2019, C-221/17, Tjebbes y otros, EU:C:2019:189). 
Esta sentencia de la Gran Sala del Tribunal de Justicia concierne a varias personas de nacionalidad neerlandesa que poseen asimismo la nacionalidad de otro Estado no miembro de la UE y con respecto a las que el Ministerio de Asuntos Exteriores se negó a examinar sus solicitudes de renovación del pasaporte nacional. La negativa de dicho ministerio se basó en la ley neerlandesa sobre la nacionalidad, que dispone que todo mayor de edad perderá esta nacionalidad si posee a la vez una nacionalidad extranjera y si, tras alcanzar la mayoría de edad, establece su residencia principal, durante un periodo ininterrumpido de diez años, fuera de los Países Bajos y de la Unión Europea. No obstante, este periodo de diez años se considerará interrumpido cuando el interesado, durante un periodo inferior a un año, establezca su residencia principal en los Países Bajos o en la Unión Europea. Del mismo modo, el periodo se interrumpirá si el interesado solicita la expedición de una declaración sobre la posesión de la nacionalidad neerlandesa, de un documento de viaje (pasaporte) o de un documento de identidad neerlandés. Un nuevo periodo de diez años comenzará a correr a partir de la expedición de cualquiera de los mencionados documentos. Por otro lado, un menor de edad perderá, en principio, la nacionalidad neerlandesa si su padre o madre pierden esta nacionalidad.

En el contexto de este marco nacional se planteó la cuestión sobre el margen de apreciación de que disponen los Estados miembros a la hora de establecer las condiciones de la pérdida de la nacionalidad, en particular si la pérdida automática de la nacionalidad neerlandesa por imperativo de la ley (ipso iure), que lleva consigo igualmente la pérdida de la ciudadanía de la Unión, es compatible con el derecho de la Unión.

El Tribunal de Justicia recordó, en primer lugar, que la situación de los ciudadanos de la Unión que poseen únicamente la nacionalidad de un solo Estado miembro y que, al perder esta nacionalidad, se ven abocados a la pérdida de la ciudadanía europea, así como de los derechos vinculados a la misma, está comprendida, por su propia naturaleza y por sus consecuencias, dentro del ámbito del derecho de la Unión. Dicho esto, el Tribunal de Justicia puso de relieve que la voluntad del legislador neerlandés fue la de establecer un régimen idóneo, entre otras cosas, para excluir los efectos perjudiciales de la posesión de múltiples nacionalidades por una misma persona. Entre los objetivos de la ley sobre la nacionalidad neerlandesa figura el de evitar que las personas obtengan o conserven la nacionalidad neerlandesa pese a no haber tenido nunca vínculo alguno con los Países Bajos o a haber dejado de tenerlo.

A este respecto, el Tribunal de Justicia estimó que un criterio que se fundamenta en la residencia habitual de los nacionales de los Países Bajos durante un periodo ininterrumpido de diez años fuera de la Unión Europea puede considerarse legítimo porque refleja la inexistencia del mencionado vínculo 
efectivo. Además, tal legitimidad viene corroborada por las disposiciones internacionales que prevén la posibilidad de que, en situaciones similares, una persona pierda la nacionalidad del Estado miembro de que se trate, siempre que se excluya el riesgo de apatridia, lo que precisamente dispone en este caso la ley neerlandesa. La referida legitimidad resulta confirmada asimismo por el hecho de que la expedición de una declaración sobre la posesión de la nacionalidad neerlandesa, de un documento de viaje o de un documento de identidad neerlandés es suficiente para considerar que la persona en cuestión manifiesta su voluntad de conservar un vínculo efectivo con los Países Bajos.

No obstante, la pérdida automática de la nacionalidad de un Estado miembro por imperativo de la ley resultaría incompatible con el principio de proporcionalidad si las normas nacionales pertinentes no permitieran, en ningún momento, un examen individual de las consecuencias que tal pérdida tendría para las personas afectadas desde el punto de vista del derecho de la Unión. Por tanto, las autoridades administrativas y los tribunales nacionales competentes deben estar en condiciones de examinar, con carácter incidental, las consecuencias de tal pérdida de nacionalidad y, eventualmente, de arbitrar el mecanismo adecuado para que la persona afectada recupere con carácter retroactivo la nacionalidad en el momento en que solicite la obtención de un documento de viaje o de cualquier otro documento que haga constar su nacionalidad. En el marco del referido examen de proporcionalidad, incumbe especialmente a las autoridades nacionales competentes y, en su caso, a los tribunales nacionales verificar si la pérdida de la nacionalidad resulta conforme con la Carta de los Derechos Fundamentales de la Unión Europea y, muy especialmente, con el derecho al respeto de la vida familiar, en relación con la obligación de tomar en consideración el interés superior del niño.

En cuanto a las circunstancias pertinentes relacionadas con tal examen, el Tribunal de Justicia mencionó, en particular, el hecho de que la persona afectada se verá expuesta a limitaciones en el ejercicio del derecho a circular y residir libremente en el territorio de los Estados miembros, que supondrán en su caso dificultades particulares para continuar desplazándose a los Países Bajos o a otro Estado miembro con el fin de mantener allí relaciones afectivas y continuadas con los miembros de su familia, de desarrollar su actividad profesional o de iniciar las gestiones y trámites necesarios para ejercer tal actividad. Resultan asimismo pertinentes, por una parte, el hecho de que la persona afectada no haya podido renunciar a la nacionalidad de un Estado tercero, y, por otra parte, el riesgo fundado de deterioro sustancial de la seguridad o de la libertad de movimientos al que se vería expuesta la persona afectada en razón de la imposibilidad con la que se encontraría de beneficiarse de la protección consular. Siempre que las autoridades administrativas y judiciales competentes estén en condiciones de llevar a cabo tal examen individual de la 
situación de la persona afectada a la luz del conjunto de circunstancias pertinentes, el derecho de la Unión no se opone a la pérdida de la nacionalidad de un Estado miembro en circunstancias como las que prevé la legislación neerlandesa.

Un nacional de un Estado miembro que ha ejercido su derecho de libre circulación y ha adquirido en otro Estado miembro la condición de trabajador gracias a la actividad que ha ejercido en el mismo durante un periodo de dos semanas - en virtud de un contrato que no es de duración determinada - antes de quedar en paro involuntario mantiene la condición de trabajador durante un periodo adicional de al menos seis meses, siempre que se haya inscrito en el servicio de empleo competente con el fin de encontrar un trabajo (Sentencia de 11 de abril de 2019, Tarola, C-483/17, EU:C:2019:309).

En el ámbito de la ciudadanía destaca también la sentencia Tarola en la que el Tribunal de Justicia interpretó el derecho de la igualdad de trato en el ámbito de la Directiva 2004/38/CE del Parlamento Europeo y del Consejo, relativa al derecho de los ciudadanos de la Unión y de los miembros de sus familias a circular y residir libremente en el territorio de los Estados miembros, en un procedimiento de petición de decisión prejudicial presentada en el marco de un litigio entre el Sr. Neculai Tarola y el Ministerio de Asuntos Sociales de Irlanda, en relación con la denegación de la solicitud presentada a efectos de que se le concediera un subsidio para solicitantes de empleo.

El Sr. Tarola es un nacional rumano que entró por primera vez en Irlanda en 2007, donde trabajó por cuenta ajena durante dos periodos de un mes ese año. Si bien no estaba acreditado que permaneciera en Irlanda entre los años 2007 y 2013, consta no obstante que volvió a trabajar por cuenta ajena en este Estado miembro durante dos meses de 2013 y, posteriormente, dos semanas de julio de 2014, y que percibió por este último empleo una remuneración de 1309 euros. Trabajó asimismo como subcontratista autónomo durante dos semanas a finales del 2014. El Sr. Tarola presentó ante el Ministerio de Asuntos Sociales una solicitud con objeto de que se le concediera un subsidio para solicitantes de empleo (jobseeker's allowance), la cual fue denegada debido a que no había aportado pruebas ni de su residencia habitual en Irlanda ni de sus recursos en el periodo comprendido entre los años 2007 y 2013. Asimismo se le denegó la prestación de asistencia social suplementaria (supplementary welfare allowance), debido a que no había podido facilitar información que acreditara el modo en que había sufragado sus necesidades y pagado el alquiler en el periodo comprendido entre septiembre de 2013 y abril de 2014. 
El órgano jurisdiccional remitente se preguntaba si debe considerarse, dadas estas circunstancias de hecho, que el Sr. Tarola había mantenido su condición de trabajador, en el sentido del art. 7, apdo. 3, letra c), de la Directiva 2004/38, por haber trabajado durante un periodo de dos semanas en julio de 2014, de manera que tiene derecho, en principio, a percibir el subsidio para solicitantes de empleo, habida cuenta de que quedó en paro involuntario y se inscribió como solicitante de empleo.

El Tribunal de Justicia recordó, en primer lugar, que la Directiva 2004/38 pretende facilitar el ejercicio del derecho fundamental e individual de circular y residir libremente en el territorio de los Estados miembros que el art. 21 TFUE, apdo. 1, confiere directamente a los ciudadanos de la Unión, y que esta directiva tiene por objeto, en particular, reforzar ese derecho. De este modo, el art. 7, apdo. 1, letra a), de la Directiva 2004/38 establece que todo ciudadano de la Unión tiene derecho a residir en el territorio de un Estado miembro distinto del Estado del que tenga la nacionalidad por un periodo superior a tres meses si tiene la condición de trabajador por cuenta ajena o por cuenta propia en el Estado miembro de acogida.

No obstante, el ciudadano de la Unión que ya no ejerza ninguna actividad por cuenta ajena o por cuenta propia en el Estado miembro de acogida mantendrá no obstante la condición de trabajador en determinadas circunstancias. Así, el ciudadano de la Unión mantendrá la condición de trabajador, sin condiciones en cuanto a la duración, siempre que se haya inscrito en el servicio de empleo competente con el fin de encontrar un trabajo si concurre alguna de las siguientes características: el ciudadano ha quedado en paro involuntario debidamente acreditado, tras haber estado empleado durante más de un año, o tras concluir un contrato de trabajo de duración determinada inferior a un año, o habiendo quedado en paro involuntario durante los primeros doce meses, en el Estado miembro de acogida. De este modo, la directiva, a través del art. 7 , apdo. 3, garantiza a todo ciudadano de la Unión que se halle en una situación de inactividad temporal el mantenimiento de la condición de trabajador, y consiguientemente de su derecho de residencia en el Estado miembro de acogida, y establece asimismo una graduación respecto de las condiciones del mantenimiento.

Ahora bien, cuando el derecho nacional excluye del disfrute del derecho a percibir prestaciones sociales a las personas que han ejercido una actividad por cuenta ajena o por cuenta propia solo durante un breve periodo, esta exclusión se aplica de igual modo a los trabajadores de otros Estados miembros que han ejercido su derecho de libre circulación.

\section{Un menor acogido según el régimen de tutela de la kafala argelina por un ciudadano de la Unión no puede ser considerado "descendiente}


directo" de dicho ciudadano a efectos del derecho de la Unión, pero el Estado miembro en el que resida ese ciudadano debe facilitar, previa evaluación, la entrada y residencia del menor en su territorio (Sentencia de 26 de marzo de 2019, SM, C-129/18, EU:C:2019:248).

En otra sentencia que interpreta la misma directiva, la Supreme Court del Reino Unido preguntó al Tribunal de Justicia, en síntesis, si la Directiva 2004/38/CE del Parlamento Europeo y del Consejo, relativa al derecho de los ciudadanos de la Unión y de los miembros de sus familias a circular y residir libremente en el territorio de los Estados miembros permite calificar a un menor de «descendiente directo» de quienes le acogieron en kafala. Un matrimonio de nacionalidad francesa, residente en el Reino Unido, solicitó a las autoridades de este país un permiso de entrada, en calidad de adoptada, de una menor argelina cuyo acogimiento se les había atribuido en Argelia bajo la fórmula de la kafala, institución del derecho de familia existente en algunos países de tradición coránica. La solicitud fue denegada por las autoridades británicas competentes.

La directiva contempla dos vías para que un menor que no sea ciudadano de la Unión pueda entrar y residir en un Estado miembro en compañía de las personas con las que tiene una "vida familiar». En el caso de los descendientes directos, la continuidad de la vida familiar se produce de manera prácticamente automática, mientras que, cuando se trata de cualquier otro miembro de la familia que esté a cargo o viva con el ciudadano de la Unión beneficiario del derecho de residencia con carácter principal, es preciso ponderar previamente las circunstancias antes de otorgarle esos derechos.

El Tribunal de Justicia, en formación de Gran Sala, analizó, en primer lugar, el instituto de la kafala y precisó que la kafala constituye, en virtud del derecho argelino, el compromiso de un adulto de hacerse cargo del cuidado, la educación y la protección del menor, de igual forma que lo haría el progenitor, y de ejercer la tutela legal sobre dicho menor. A diferencia de la adopción, que está prohibida por el derecho argelino, el acogimiento en régimen de kafala no confiere al menor la condición de heredero del tutor. Por otra parte, la kafala concluye con la mayoría de edad del menor y puede revocarse a solicitud de los padres biológicos o del tutor.

El Tribunal de Justicia considera que a falta de una remisión expresa al derecho nacional, se desprende de las exigencias tanto de la aplicación uniforme del derecho de la Unión como del principio de igualdad que el tenor de la directiva relativa a la libre circulación normalmente debe ser objeto en toda la Unión de una interpretación autónoma y uniforme. En ese contexto, el Tribunal de Justicia señaló que el concepto de «descendiente directo» supone generalmente que existe un vínculo de filiación. Ese concepto de vínculo debe 
entenderse en sentido amplio y, por consiguiente, debe interpretarse que el concepto de «descendiente directo» de ciudadano de la Unión abarca tanto al hijo biológico como al hijo adoptivo de dicho ciudadano, siempre que resulte acreditado que la adopción crea un vínculo jurídico de filiación entre el menor y el ciudadano de la Unión de que se trate. El Tribunal de Justicia observó que, dado que el acogimiento de un menor en régimen de kafala argelina no crea un vínculo de filiación entre el menor y su tutor, no puede considerarse que un menor que se halla bajo la tutela legal de ciudadanos de la Unión con arreglo a dicha institución sea "descendiente directo» de un ciudadano de la Unión.

No obstante, el Tribunal de Justicia consideró que ese menor encajará en otro concepto de la directiva relativa a la libre circulación, concretamente el de «otro miembro de la familia», que sí puede abarcar la situación de un menor que, respecto de determinados ciudadanos de la Unión, se halla bajo un régimen de tutela legal como puede ser la kafala argelina y cuyo cuidado, educación y protección han asumido dichos ciudadanos con arreglo a un compromiso adquirido en virtud del derecho del país de origen del menor. Destacó a ese respecto que el objetivo de la directiva relativa a la libre circulación consiste en "mantener la unidad de la familia en un sentido amplio», facilitando la entrada y la residencia de las personas que mantengan con un ciudadano de la Unión relaciones familiares estrechas y estables por razón de circunstancias de hecho específicas, como una dependencia financiera, una relación de convivencia o motivos graves de salud. Así pues, los Estados miembros deben prever la posibilidad de que «los miembros de la familia en un sentido amplio» obtengan una decisión sobre su solicitud que esté basada en un estudio detenido de su situación personal que tenga en cuenta las diversas circunstancias pertinentes y que, en caso de denegación, esté motivada. Además, el margen de apreciación que corresponde a los Estados miembros se ejercerá a la luz y en consideración al respeto de las disposiciones de la Carta de los Derechos Fundamentales de la Unión Europea, especialmente el derecho al respeto de la vida familiar y la protección del interés superior del menor. Por lo tanto, en caso de que se demuestre que, en circunstancias normales, el menor y su tutor (que es ciudadano de la Unión) llevarán una vida familiar efectiva y que el menor depende de su tutor, las exigencias vinculadas al derecho fundamental al respeto de la vida familiar, junto con la obligación de tener en cuenta el interés superior del menor, en principio, requerirán que se otorgue a este el derecho de entrada y residencia al objeto de permitir que viva con su tutor en el Estado miembro de acogida de este.

\section{La exigencia relativa al mantenimiento de la sede y de la dirección efec- tiva de la sociedad en Portugal contenida en las condiciones planteadas}


por el Gobierno portugués en el marco de la reprivatización de TAP es compatible con la libertad de establecimiento, pero el derecho de la Unión se opone a la obligación de mantener y desarrollar el centro de operaciones (bub) nacional (Sentencia de 27 de febrero, Associação Peço a Palavra y otros, C-563/17, EU:C:2019:144).

En el marco de la libertad de establecimiento destaca la sentencia en la que el Tribunal de Justicia examinó las condiciones planteadas por el Gobierno portugués en el marco de la reprivatización de TAP. La recurrente en el litigio nacional era una asociación que se oponía al procedimiento de reprivatización de la compañía aérea portuguesa TAP, solicitando que se anulara el pliego de condiciones adoptado por el Gobierno portugués en enero de 2015, en el marco de esa reprivatización. La asociación sostenía que algunas de las condiciones contenidas en ese pliego vulneraban las libertades de establecimiento y de prestación de servicios recogidas en el tratado. El Supremo Tribunal Administrativo decidió plantear al Tribunal de Justicia cuestiones sobre la conformidad, con el derecho de la Unión, de esas condiciones consistentes en la obligación de conservar en Portugal la sede y la dirección efectiva de la compañía, la capacidad cumplir las obligaciones de servicio público y la obligación de mantener y desarrollar el centro de operaciones (bub) nacional existente.

El Tribunal de Justicia declaró que el art. 49 TFUE (prohibición de las restricciones a la libertad de establecimiento) no se opone a las dos primeras condiciones mencionadas. En cambio, la exigencia de que el adquirente de la participación garantice el mantenimiento y el desarrollo del centro de operaciones $(h u b)$ nacional existente constituye una restricción injustificada a la libertad de establecimiento.

En primer lugar, en lo que atañe a la exigencia en virtud de la cual el comprador está obligado a cumplir las obligaciones de servicio público en cuestión, el Tribunal de Justicia recordó que, según el pliego de condiciones, esta exigencia consiste en la capacidad para garantizar el cumplimiento de las obligaciones de servicio público que incumben a TAP, y que Portugal impuso, en el pasado, a las compañías aéreas que cubren las líneas aéreas regulares entre Portugal y sus regiones autónomas y cuya conformidad al Reglamento (CE) n. ${ }^{\circ}$ 1008/2008 del Parlamento Europeo y del Consejo, sobre normas comunes para la explotación de servicios aéreos en la Comunidad, no había sido discutida. Habida cuenta de que dicho reglamento ha llevado a cabo una armonización exhaustiva en la Unión en el ámbito de las obligaciones de servicio público en el sector de los servicios de transporte aéreo, toda medida nacional adoptada en ese ámbito debe apreciarse a la luz de las disposiciones de dicha medida de armonización (es decir, el reglamento) y no de las del 
derecho primario (es decir, la libertad de establecimiento reconocida en el art. 49 TFUE). En la medida en que el pliego de condiciones se limita a exigir el respeto, por el nuevo accionista seleccionado a raíz del procedimiento de reprivatización de que se trata en el litigio principal, de eventuales obligaciones de servicio público impuestas a TAP de conformidad con los requisitos materiales y de procedimiento establecidos en el reglamento, dicha medida nacional es conforme con el derecho de la Unión, sin que sea necesario apreciarla a la luz de la libertad de establecimiento.

En cambio, dado que las obligaciones relativas, respectivamente, al mantenimiento del domicilio social y de la dirección efectiva en Portugal y al mantenimiento y desarrollo del centro de operaciones ( $h u b)$ nacional existente no se vinculan a un ámbito armonizado por el reglamento, deben apreciarse a la luz del derecho primario, en particular a la luz de la libertad de establecimiento. Según el Tribunal de Justicia, esas exigencias constituyen efectivamente restricciones a la libertad de establecimiento, puesto que obstaculizan o hacen menos interesante el ejercicio de esa libertad, en la medida en que llevan consigo, para el comprador, restricciones a la libertad de decisión de que disponen normalmente los órganos de TAP.

A continuación, el Tribunal de Justicia examinó si esas condiciones pueden estar justificadas a la luz del derecho de la Unión. A este respecto, consideró que la necesidad de asegurar un servicio de interés general, que consiste en garantizar la suficiencia de los servicios regulares de transporte aéreo hacia y desde terceros países de habla portuguesa con los que Portugal mantiene vínculos históricos, culturales y sociales especiales, constituye una razón imperiosa de interés general que podría justificar tales medidas.

Asimismo, el Tribunal de Justicia declaró que la exigencia relativa al mantenimiento de la sede y de la dirección efectiva de la sociedad en Portugal es proporcionada desde el punto de vista del criterio de la razón imperiosa de interés general, toda vez que ese mantenimiento es indispensable para garantizar los derechos de tráfico aéreo reconocidos en virtud de los acuerdos bilaterales celebrados entre ese Estado miembro y los terceros países mencionados. En efecto, esos acuerdos supeditan los derechos de tráfico de que TAP disfruta en las rutas aéreas con tales países al mantenimiento del centro de actividad principal de TAP en Portugal. El traslado de la sede a otro país podría además suponer una pérdida de validez de la licencia de explotación y del certificado de operador aéreo expedidos a TAP por la autoridad portuguesa competente, que constituiría un obstáculo a la explotación de cualquier servicio regular de transporte aéreo, incluidos los que tienen como destino los terceros países de expresión portuguesa en cuestión que representan una parte significativa de las actividades de TAP. Además, la proporcionalidad de dicha exigencia viene 
corroborada por el hecho de que esta no se opone a que TAP cree centros de actividad secundarios, como las filiales o sucursales fuera de Portugal.

Sin embargo, el Tribunal de Justicia considera que la exigencia relativa al mantenimiento y al desarrollo del centro de operaciones $(b u b)$ nacional existente va más allá de lo necesario para alcanzar el objetivo perseguido de conectividad de los terceros países de expresión portuguesa de que se trata.

Una ley nacional no puede invalidar, mediante una norma retroactiva, general y automática, los contratos de crédito celebrados con prestamistas extranjeros que no estaban autorizados a prestar servicios de crédito en dicho Estado miembro (Sentencia de 14 de febrero de 2019, Milivojević, C-630/17, EU:C:2019:123).

En 2007 la Sra. Milivojević, nacional croata, celebró con Raiffeisenbank, con sede en Austria, un contrato de crédito no renovable a fin de realizar obras de renovación en su domicilio y habilitarlo para apartamentos de alquiler. El préstamo se contrató con ayuda de un intermediario residente en Croacia e incluía una cláusula atributiva de competencia alternativa, bien a favor de los tribunales austriacos bien de los tribunales croatas. Para garantizar el reembolso del préstamo, la Sra. Milivojević firmó además una escritura notarial de constitución de una hipoteca que surge de este contrato que posteriormente fue inscrita en el Registro de la Propiedad croata.

En 2015, la Sra. Milivojević interpuso una demanda contra Raiffeisenbank solicitando que se declarase la nulidad del contrato de crédito y de la escritura notarial así como que se cancelase la inscripción de la hipoteca en el Registro de la Propiedad. Mientras que Raiffeisenbank sostenía que ese contrato se celebró en Austria, la Sra. Milivojević afirma que se celebró en Croacia. En julio de 2017, entró en vigor una ley nacional que prevé la nulidad retroactiva de los contratos de crédito celebrados en Croacia con un prestamista extranjero que no tiene los permisos exigidos o la aprobación de las autoridades croatas y que podría ser aplicable al litigio principal.

El tribunal remitente estimaba, por una parte, que si se determina que el contrato en cuestión se celebró en Croacia, este sería nulo de pleno derecho y, por otra, que dicha normativa puede obstaculizar la libertad de Raiffeisenbank de prestar servicios financieros. Preguntaba, en esencia, si ello es contrario a la libre prestación de servicios en el mercado interior de la Unión y también sobre diversos aspectos relacionados con su competencia internacional para conocer del asunto principal, teniendo en cuenta lo dispuesto en el Reglamento (UE) n. ${ }^{\circ}$ 1215/2012 del Parlamento Europeo y del Consejo, relativo a la competencia judicial, el reconocimiento y la ejecución de resoluciones judiciales en materia civil y mercantil. Asimismo, preguntaba si el contrato en 
cuestión podría calificarse como «contrato celebrado con un consumidor» y si el litigio principal estaba comprendido en el ámbito de las reglas de competencia exclusiva en materia de derechos reales inmobiliarios.

El Tribunal de Justicia se declara competente para examinar la compatibilidad con la libre prestación de servicios de la ley de 14 de julio de 2017. A este respecto, aun cuando Croacia sostiene que el derecho de la Unión no es aplicable al contrato en cuestión porque este último se celebró antes de la fecha de adhesión de Croacia a la Unión, no puede estimarse este argumento, porque el contrato continúa produciendo efectos con posterioridad a esa fecha. Además, como resulta del Tratado de Adhesión de Croacia, las disposiciones de los tratados originarios vinculan a Croacia desde la fecha de su adhesión y, por ello, se aplican a los efectos futuros de una situación nacida antes de dicha fecha.

Más adelante, respecto a la libre prestación de servicios, el Tribunal de Justicia recuerda que este principio exige eliminar toda discriminación en perjuicio del prestador de servicios establecido en un Estado miembro distinto debido a su nacionalidad, así como suprimir cualquier restricción, cuando pueda prohibir, obstaculizar o hacer menos interesantes las actividades del prestador establecido en otro Estado miembro.

El Tribunal de Justicia observa que, en el ordenamiento jurídico croata, la nulidad de los contratos de crédito celebrados con un prestamista no autorizado se regula, al mismo tiempo, en la ley de 14 de julio de 2017 y en la ley del contrato de crédito al consumo de 30 de septiembre de 2015 . Al constatar que para el periodo del 1 de julio de 2013, fecha de la adhesión de Croacia a la Unión, al 30 de septiembre de 2015, la citada nulidad era válida únicamente para los contratos de crédito celebrados por los prestamistas no autorizados que tengan su domicilio fuera de Croacia, el Tribunal de Justicia considera que, en dicho periodo, el derecho croata discrimina directamente a los prestamistas establecidos fuera de Croacia. A partir de esa fecha, dado que el régimen de nulidad se aplicaba indistintamente a todos los prestamistas no autorizados, la ley de 14 de julio de 2017 implica una restricción al ejercicio de la libre prestación de servicios.

El Tribunal de Justicia examina posteriormente, por lo que se refiere al periodo del 1 de julio de 2013 al 30 de septiembre de 2015, si la ley nacional puede estar justificada por razones de orden público, de seguridad pública o de salud pública, y señala que para poder invocar esa justificación es necesario que exista una amenaza real y suficientemente grave que afecte a un interés fundamental de la sociedad, ya que las consideraciones de naturaleza económica no pueden justificar una excepción a la libre prestación de servicios. En lo que atañe al periodo en el que el régimen de nulidad de los contratos de crédito en cuestión se aplicaba indistintamente, el Tribunal de Justicia 
concluyó que este régimen excedía manifiestamente los límites de lo necesario para alcanzar los objetivos que persigue.

En estas circunstancias, el Tribunal de Justicia concluye que el art. 56 TFUE se opone a una normativa nacional en virtud de la cual los contratos de crédito y cualesquiera otros actos jurídicos basados en tales contratos son nulos, con carácter retroactivo, desde la fecha de su celebración, cuando se han concluido con un prestamista establecido en un Estado miembro distinto al Estado del destinatario de la prestación y que no cuenta con todas las autorizaciones requeridas, expedidas por las autoridades competentes de dicho Estado miembro.

Por lo que se refiere a la competencia internacional, el Tribunal de Justicia recuerda que en el sistema del Reglamento sobre la Competencia Judicial, la competencia de los órganos jurisdiccionales del Estado miembro en el que el demandado tiene su domicilio constituye el principio general. Por ello, una legislación nacional que establece reglas de competencia que constituyen excepciones a este principio general, que no están previstas por otra disposición de dicho reglamento, contraviene el sistema estipulado por ese reglamento.

En cuanto a la posible calificación de "contrato celebrado con un consumidor» de un contrato de crédito celebrado por un deudor a fin de realizar obras de renovación en un bien inmueble que es su domicilio con el fin, en particular, de prestar en este servicios de alojamiento turístico, el Tribunal de Justicia considera que el deudor podrá beneficiarse de las referidas disposiciones solamente en caso de que el vínculo entre el citado contrato y la actividad profesional sea tan tenue que resulte evidente que el referido contrato persigue esencialmente fines privados, lo que corresponde comprobar al órgano jurisdiccional nacional.

Por último, respecto a las pretensiones de que se declare la nulidad del contrato en cuestión y de la escritura notarial de constitución de una hipoteca, el Tribunal de Justicia constata que se basan en un derecho personal que solo puede invocarse contra Raiffeisenbank. En cambio, en cuanto a la pretensión de que se cancele la inscripción de una hipoteca del Registro de la Propiedad, procede observar que la hipoteca es un derecho real que produce efectos erga omnes y, por ello, es competencia exclusiva del tribunal del Estado donde se halla el inmueble.

\section{AGRICULTURA}

El logotipo de producción ecológica de la Unión Europea no se puede utilizar para la carne procedente de animales que hayan sido objeto de 
un sacrificio ritual sin aturdimiento previo, pues este tipo de sacrificio no respeta las normas más exigentes sobre bienestar animal (Sentencia de 26 de febrero de 2019, Euvre d'assistance aux bêtes d'abattoirs, C-497/17, EU:C:2019:137).

La asociación francesa Cuvre d'assistance aux bêtes d'abattoirs (OABA) solicitó al ministro francés de Agricultura y Alimentación que se prohibiera el uso de la mención "agricultura ecológica» $(\mathrm{AB})$ en la publicidad y los envases de hamburguesas de carne de vacuno con certificación halal procedente de animales sacrificados sin aturdimiento previo. La entidad certificadora responsable, Ecocert, denegó implícitamente la solicitud de OABA, a raíz de lo cual esta organización interpuso un recurso que fue desestimado por el tribunal competente.

Se preguntaba al Tribunal de Justicia si las normas aplicables del derecho de la Unión, resultantes, en particular, del Reglamento (CE) n.o 834/2007 del Consejo, sobre producción y etiquetado de los productos ecológicos, de su Reglamento de aplicación [Reglamento (CE) n. ${ }^{\circ}$ 889/2008 de la Comisión], y del Reglamento (CE) n. ${ }^{\circ}$ 1099/2009 del Consejo, relativo a la protección de los animales en el momento de la matanza, deben interpretarse en el sentido de que autorizan o de que prohíben la «expedición de la etiqueta europea $A B$ » a los productos procedentes de animales que han sido objeto de un sacrificio ritual sin aturdimiento previo.

El Tribunal de Justicia constata que, en los reglamentos mencionados, el legislador de la Unión reitera su voluntad de garantizar un nivel elevado de bienestar animal en el ámbito de este modo de producción, que se caracteriza por la observancia de normas más estrictas en materia de bienestar animal en todos los lugares y en todas las etapas de la producción en que sea posible incrementarlo, incluida la del sacrificio. El Tribunal de Justicia recuerda que existen estudios científicos que demuestran que el aturdimiento es la técnica que respeta en mayor medida el bienestar animal en el momento del sacrificio. A continuación, el Tribunal de Justicia indica que la práctica del sacrificio ritual, en el que se puede matar al animal sin aturdimiento previo, que en el ámbito de la Unión se autoriza con carácter excepcional y con el único fin de garantizar el respeto de la libertad de religión, no es tan eficaz para reducir el dolor, la angustia o el sufrimiento animal como el sacrificio precedido de aturdimiento. Señala que, en efecto, el aturdimiento es necesario para causar en el animal una pérdida de consciencia y de sensibilidad que reduzca considerablemente el sufrimiento.

Sobre este particular, observa que, si bien el sacrificio sin aturdimiento previo exige degollar con precisión al animal con un cuchillo afilado para 
reducir en la medida de lo posible su sufrimiento, el empleo de esta técnica no permite reducir al mínimo el sufrimiento del animal.

El Tribunal de Justicia concluye que, en consecuencia, los métodos específicos de sacrificio prescritos por ritos religiosos, que se realizan sin aturdimiento previo, no equivalen, en términos de garantía de un elevado nivel de protección del bienestar animal en el momento de la matanza, al método de sacrificio con aturdimiento previo, en principio impuesto por el derecho de la Unión.

Por último, señala que el objetivo de las normas de la Unión sobre etiquetado de los productos ecológicos es «mantener y justificar la confianza del consumidor en los productos etiquetados como ecológicos» y declara que es importante garantizar que los consumidores puedan tener la seguridad de que los productos con el logotipo ecológico de la Unión Europea, al que en realidad se refiere el tribunal remitente, efectivamente se han obtenido observando las normas más exigentes, entre ellas las relativas al bienestar animal. El Tribunal de Justicia estima que, por consiguiente, las normas del derecho de la Unión no autorizan la utilización del logotipo de producción ecológica de la Unión Europea para productos procedentes de animales que hayan sido objeto de un sacrifico ritual sin aturdimiento previo.

\section{DERECHO DE LA COMPETENCIA}

La financiación de un régimen de apoyo a favor de las empresas que producen electricidad a partir de fuentes de energías renovables no implica recursos estatales en el sentido del art. 107 TFUE porque un recargo para financiar la producción de energías renovables no puede asimilarse a una tasa dado que la ley nacional no obliga a los proveedores que suministran a los clientes finales a repercutir en estos los importes abonados en concepto de dicho recargo (Sentencia de 28 de marzo de 2019, Alemania/Comisión, C-405/16P, EU:C:2019:268).

En materia de ayudas de Estado conviene destacar una sentencia que matiza la jurisprudencia anterior sobre la noción de recursos estatales. El Tribunal de Justicia anuló no solo la sentencia del Tribunal General, sino también una decisión de la Comisión. En esta decisión, la Comisión constató que la ley sobre las energías renovables alemana (EEG 2012) conllevaba ayudas de Estado, aprobándolas al mismo tiempo en gran medida y ordenando una recuperación limitada para las ayudas que no podía declarar como compatibles con el mercado interior. 
La ley sobre las energías renovables establecía un régimen de apoyo en favor de las empresas que producen electricidad a partir de fuentes de energía renovable y de gas de minería. Esta ley garantizaba a estos productores un precio superior al precio de mercado. Para financiar esta medida de apoyo, dicha ley preveía un «recargo EEG» que recaía sobre los proveedores que suministraban a los clientes (consumidores finales), que en la práctica se repercutía a estos últimos y que representaba de un $20 \%$ a un $25 \%$ del importe total de la factura de un consumidor final medio. El recargo EEG debía abonarse a los gestores de redes de transporte interregional obligados a comercializar la electricidad de energías renovables.

El Tribunal de Justicia estimó el recurso de casación, fallando que el Tribunal General incurrió en un error al concluir que los fondos generados por el recargo EEG constituían fondos estatales. De ello resulta que falta un elemento necesario para calificar como ayudas las ventajas que se derivan de los mecanismos establecidos por la EEG 2012.

El elemento determinante para que el Tribunal de Justicia concluyera que no había recursos estatales fue el hecho de que el recargo EEG no puede asimilarse a una tasa dado que la EEG 2012 no obliga a los proveedores que suministran a los clientes finales a repercutir en estos los importes abonados en concepto de recargo EEG. El hecho de que, en la práctica, la carga financiera que resulta del recargo EEG se repercutía en los clientes finales no basta a este respecto. Esta conclusión genera cierta controversia debido a que, hasta esta sentencia, el Tribunal de Justicia no concibió, en su jurisprudencia reciente, este elemento como relevante para desacreditar la existencia de recursos estatales.

Además, el Tribunal de Justicia estimó que no se había acreditado que el Estado tuviera la facultad de disponer de los fondos generados por el recargo EEG ni siquiera que ejerciese un control público sobre los gestores de redes de transporte encargados de gestionar esos fondos.

El Tribunal de Justicia señaló, en particular, que el hecho de que los fondos que se derivan del recargo EEG se adscriban exclusivamente a la financiación de los regímenes de apoyo y de compensación, en virtud de las disposiciones de la EEG de 2012, más bien demuestra precisamente que el Estado no podía disponer de esos fondos, es decir, decidir una adscripción distinta. Además, aun cuando los elementos tenidos en cuenta por el Tribunal General permiten efectivamente concluir que las autoridades públicas ejercen un control de la buena ejecución de la EEG 2012, no permiten, en cambio, llegar a la conclusión de que exista un control público sobre los fondos generados por el recargo EEG.

\section{Si las autoridades nacionales constatan que los requisitos de un regla- mento de exención por categorías no se cumplen, el art. 108 TFUE,}


apdo. 3, exige a la autoridad nacional recuperar por su propia iniciativa la ayuda que se ha concedido de conformidad con dicho reglamento, sin que la autoridad nacional pueda generar una confianza legítima en la regularidad de dicha ayuda en el beneficiario de esta (Sentencia de 5 de marzo de 2019, Eesti Pagar, C-349/17, EU:C:2019:172).

Este asunto versa sobre versa sobre la interpretación del anterior reglamento general de exención por categorías — Reglamento (CE) n. ${ }^{\circ}$ 800/2008 de la Comisión, por el que se declaran determinadas categorías de ayuda compatibles con el mercado común en aplicación de los artículos [107 TFUE y 108 TFUE] - y, sobre todo, sobre la obligación que incumbe a las autoridades nacionales de recuperar por su propia iniciativa una ayuda ilegal concedida en incumplimiento de un reglamento de exención, así como sobre la interpretación del principio general del derecho de la Unión de protección de la confianza legítima en materia de recuperación de una ayuda ilegal, sobre el plazo de prescripción aplicable a la recuperación por las autoridades nacionales por su propia iniciativa de una ayuda ilegal y, por último, sobre la obligación de los Estados miembros de reclamar intereses al proceder a tal recuperación.

La petición de decisión prejudicial se presentó en el marco de un litigio entre Eesti Pagar AS, por un lado, y la Fundación para el Desarrollo del Empresariado y el Ministerio de Economía y Comunicaciones, de Estonia, por otro lado, en relación con la legalidad de una decisión de la fundación, confirmada por el ministerio al resolver un recurso de alzada, por la que se ordena recuperar de Eesti Pagar la cantidad de más de medio millón de euros, más los intereses, que la fundación le había abonado anteriormente en concepto de ayuda. La empresa Eesti Pagar recibió esta ayuda en 2008 para la adquisición y la instalación de una línea de producción de pan de molde. Esta ayuda se cofinanciaba con cargo al Fondo Europeo de Desarrollo Regional (FEDER). No obstante, en 2013, la fundación informó a Eesti Pagar de que el contrato de compraventa no satisfacía el requisito del efecto incentivador de la ayuda, de modo que se había concedido una ayuda de Estado ilegal a Eesti Pagar e inició un procedimiento de recuperación de la ayuda concedida anteriormente.

Recuerda, primero, que los Estados miembros están obligados, por una parte, a notificar a la Comisión toda medida que pretenda establecer o modificar una ayuda en el sentido del art. 107 TFUE, apdo. 1, y, por otra parte, a no aplicar dicha medida mientras esta institución no haya adoptado una decisión definitiva sobre la misma, con arreglo a lo dispuesto en el art. 108 TFUE, apdo. 3. Ahora bien, el Consejo de la Unión Europea puede adoptar los reglamentos apropiados para la aplicación de los arts. 107 TFUE y 108 TFUE y determinar, en particular, las condiciones para la aplicación del apdo. 3 del art. 108 TFUE y las categorías de ayudas que quedan excluidas del 
procedimiento previsto en esta última disposición. Asimismo, en virtud del art. 108 TFUE, apdo. 4, la Comisión puede adoptar reglamentos relativos a las categorías de ayudas públicas sobre las que el Consejo haya determinado, con arreglo al art. 109 TFUE, que pueden quedar exentas del procedimiento establecido en el art. 108 TFUE, apdo. 3 (los llamados reglamentos generales de exención por categorías).

Para dar respuesta a una seria de cuestiones planteadas por el órgano jurisdiccional remitente, el Tribunal de Justicia interpretó primero la noción de efecto incentivador, que se cumple si antes de comenzar a trabajar en el proyecto o actividad, el beneficiario ha presentado una solicitud de ayuda al Estado miembro de que se trate. A este efecto, este requisito debe interpretarse en el sentido de que se comienza a "trabajar en el proyecto o actividad», a efectos del reglamento de exención por categorías, cuando se realiza un primer pedido de equipos destinados a ese proyecto o actividad mediante la formalización de un compromiso incondicional y jurídicamente vinculante antes de presentarse la solicitud de ayuda, con independencia de la cuantía de los eventuales costes de rescisión de tal compromiso.

De este modo, si las autoridades nacionales constatan que los requisitos de un reglamento de exención por categorías no se cumplen, el art. 108 TFUE, apdo. 3, exige a la autoridad nacional recuperar por su propia iniciativa la ayuda que ha concedido de conformidad con dicho reglamento. Por añadidura, una autoridad nacional no puede, al conceder una ayuda aplicando erróneamente el reglamento general de exención por categorías, generar una confianza legítima en la regularidad de dicha ayuda en el beneficiario de esta.

Por lo que respecta los plazos de prescripción de dicha ayuda concedida, el Tribunal de Justicia consideró que, cuando una autoridad nacional ha concedido una ayuda en virtud de un fondo estructural aplicando erróneamente el reglamento general de exención por categorías, hay intereses financieros de la Unión en juego. Por tanto, el plazo de prescripción aplicable a la recuperación de la ayuda ilegal es, si se cumplen los requisitos de aplicación del Reglamento (CE, Euratom) n.o 2988/95 del Consejo, relativo a la protección de los intereses financieros de las Comunidades Europeas, de cuatro años, conforme al art. 3, apdo. 1, de este reglamento, o, en su defecto, el plazo previsto por el derecho nacional aplicable.

En todo caso, cuando una autoridad nacional procede por su propia iniciativa a la recuperación de una ayuda que ha concedido erróneamente a tenor de un reglamento general de exención por categorías, le incumbe reclamar intereses al beneficiario de esa ayuda conforme a las normas del derecho nacional aplicable. No obstante, conforme al principio de efectividad, el derecho nacional no puede tener como consecuencia impedir la aplicación del derecho de la Unión en la medida en que hiciera imposible la obligación 
que tienen los tribunales o autoridades nacionales de garantizar el respeto del art. 108 TFUE, apdo. 3. A este respecto, el art. 108 TFUE, apdo. 3, exige que tales normas garanticen la recuperación íntegra de la ayuda ilegal y que, por tanto, se ordene en particular al beneficiario de la ayuda el pago de los intereses correspondientes a todo el periodo durante el que se benefició de esa ayuda y a un tipo igual al que se habría aplicado si hubiese tenido que pedir prestado en el mercado el importe de la ayuda en el curso de ese periodo.

El concepto de "empresa", en el sentido del art. 101 TFUE, no puede tener un alcance diferente en el ámbito de la imposición por la Comisión de multas y en el de las acciones por daños y perjuicios por infracción de las normas de competencia de la Unión (Sentencia de 14 de marzo de 2019, Skanska Industrial Solutions y otros, C-724/17, EU:C:2019:204).

En el ámbito de prácticas colusorias, esta petición de decisión prejudicial tenía por objeto la interpretación del art. 101 TFUE y del principio de efectividad del derecho de la Unión en relación con la normativa aplicable en el ordenamiento jurídico finlandés a las acciones de indemnización por infracción del derecho de la Unión en materia de competencia. Esta petición se había presentado en el marco de un litigio entre el Ayuntamiento de Vantaa, Finlandia, por un lado, y el conglomerado de varias empresas del grupo Skanska, por otro lado, en relación con la reparación del perjuicio resultante de una práctica colusoria en el mercado del asfalto en Finlandia que el ayuntamiento solicitaba a las empresas.

En primer lugar, el órgano jurisdiccional remitente preguntaba, en esencia, si el art. 101 TFUE debe interpretarse en el sentido de que, en una situación en la que todas las acciones de las sociedades que participaron en una práctica colusoria prohibida por dicho artículo fueron adquiridas por otras sociedades, que disolvieron aquellas sociedades y prosiguieron sus actividades comerciales, las sociedades adquirentes pueden ser declaradas responsables del perjuicio causado por esa práctica colusoria, a lo que el Tribunal de Justicia respondió afirmativamente. En efecto, el Tribunal consideró que concepto de «empresa», en el sentido del art. 101 TFUE, que es un concepto autónomo del derecho de la Unión, no puede tener un alcance diferente en el ámbito de la imposición por la Comisión de multas con arreglo al art. 23, apdo. 2, del Reglamento n. ${ }^{\circ} 1 / 2003$ y en el de las acciones por daños y perjuicios por infracción de las normas de competencia de la Unión. En efecto, si una empresa responsable del perjuicio ocasionado por una infracción de las normas de competencia de la Unión pudiera eludir su responsabilidad simplemente por el hecho de que su identidad se ha visto modificada como conse- 
cuencia de reestructuraciones, cesiones u otros cambios de carácter jurídico u organizativo, se pondrían en peligro el objetivo perseguido por este sistema y el efecto útil de dichas normas.

Una autoridad nacional de competencia puede imponer a una empresa, en una misma resolución, una multa por infracción del derecho nacional de la competencia y una multa por infracción del art. 102 TFUE, pero en esa situación la autoridad nacional de competencia debe cerciorarse de que las multas, consideradas conjuntamente, son proporcionadas a la naturaleza de la infracción (Sentencia de 3 de abril de 2019, Powszechny Zakład Ubezpieczeń na Życie, C-617/17, EU:C:2019:283).

La petición de decisión prejudicial tenía por objeto la interpretación del principio non bis in idem recogido en el art. 50 de la Carta de los Derechos Fundamentales de la Unión Europea, y del art. 3, apdo. 1, del Reglamento n. ${ }^{o} 1 / 2003$, relativo a la aplicación de las normas sobre competencia previstas en los arts. 101 y 102 del tratado. El litigio ante el tribunal nacional oponía al presidente de la Oficina de Protección de la Competencia y de los Consumidores, respecto a una resolución impuesta a una empresa polaca activa en el mercado de los seguros de vida de grupo para trabajadores en Polonia, debido a un abuso de posición dominante. Dicha autoridad había impuesto a la empresa una sanción que comprendía, por una parte, una multa en concepto de infracción de las disposiciones del derecho nacional de la competencia durante el periodo comprendido entre el 1 de mayo de 2001 y el 25 de octubre de 2007, y, por otra parte, una multa de en concepto de infracción del art. 102 TFUE durante el periodo comprendido entre el 1 de mayo de 2004, fecha de la adhesión de la República de Polonia a la Unión, y el 25 de octubre de 2007.

La empresa, recurrente en el litigio principal, alegó que había sido sancionada dos veces por una infracción del derecho de la Unión, a saber, una primera vez, de manera directa, sobre la base del art. 102 TFUE, en relación con el art. 5 del Reglamento n. ${ }^{\circ}$ 1/2003, y, una segunda vez, de manera indirecta, en virtud del derecho nacional de la competencia.

El Tribunal de Justicia recordó, al respecto, que el derecho de la Unión y el derecho nacional en materia de competencia se aplican paralelamente, ya que consideran las prácticas restrictivas desde aspectos diferentes y su ámbito de aplicación no es idéntico. Por tanto, el principio non bis in idem no es aplicable en una situación en la que la autoridad nacional de competencia aplica en paralelo, de conformidad con el art. 3, apdo. 1, del Reglamento n. ${ }^{\circ}$ $1 / 2003$, el derecho nacional de la competencia y las normas sobre competencia de la Unión y sanciona, con arreglo al art. 5 de dicho reglamento, a una 
empresa imponiéndole, en una misma resolución, una multa por la infracción del mencionado dserecho y una multa por incumplir dichas normas.

No obstante, en caso de que la autoridad nacional de competencia decida imponer una multa por infracción del art. 102 TFUE, dicha autoridad está obligada a ejercer su competencia respetando el derecho de la Unión. Así pues, cuando, en una misma resolución, la autoridad nacional de competencia imponga dos multas para sancionar una infracción del derecho nacional de la competencia y una infracción del art. 102 TFUE, dicha autoridad deberá cerciorarse de que las multas consideradas conjuntamente son proporcionadas a la naturaleza de la infracción, lo que, en el litigio principal, corresponde verificar al órgano jurisdiccional remitente.

El art. 102 TFUE y el principio de efectividad se oponen a una norma nacional, que, por una parte, establece que el plazo de prescripción de las acciones por daños empiezan a correr a partir de la fecha en la que la persona perjudicada tuvo conocimiento de su derecho a indemnización, aun cuando no se conociese el responsable de la infracción y, por otra parte, no prevé posibilidad alguna de suspensión o de interrupción de ese plazo en el transcurso de un procedimiento seguido ante la autoridad nacional de la competencia (Sentencia de 28 de marzo de 2019, Cogeco Communications, C-637/17, EU:C:2019:263).

En el ámbito de un litigio entre, por una parte, Cogeco Communications Inc. y, por otra, Sport TV Portugal, SA, Controlinveste-SGPS, SA y NOS-SGPS, SA, en relación con el resarcimiento del perjuicio sufrido como consecuencia de las prácticas contrarias a la competencia de Sport TV Portugal, que había sido multado por abuso de su posición dominante, en el sentido tanto del art. 102 TFUE como de la disposición nacional correspondiente, se planteó una petición de decisión prejudicial que tenía por objeto la interpretación de la Directiva 2014/104/UE del Parlamento Europeo y del Consejo, relativa a determinadas normas por las que se rigen las acciones por daños en virtud del derecho nacional, por infracciones del derecho de la competencia de los Estados miembros y de la Unión Europea, así como del art. 102 TFUE $\mathrm{y}$ de los principios de equivalencia y de efectividad.

Las demandadas en el litigio principal sostenían que, aun suponiendo que Cogeco Communications tuviera derecho a obtener la indemnización por el perjuicio que afirma haber sufrido, el derecho a la indemnización que invoca habría prescrito. El Tribunal de Justicia consideró que la directiva no se aplicaba al litigio principal, pues el recurso se interpuso antes de la expiración del plazo de transposición de la Directiva 2014/104 y, en la fecha de 
interposición de ese recurso, todavía no se había incorporado al ordenamiento jurídico portugués esa directiva.

No obstante, examinó el problema directamente bajo el art. 102 TFUE así como los principios de efectividad y equivalencia, preguntándose si se oponen a una norma nacional que, por una parte, prevé que el plazo de prescripción por lo que respecta a las acciones por daños se fijará en tres años y empezará a correr a partir de la fecha en la que la persona perjudicada tuvo conocimiento de su derecho a indemnización, aun cuando el responsable de la infracción y el alcance exacto del perjuicio no se conozcan, y, por otra parte, no prevé ninguna posibilidad de suspensión o interrupción de ese plazo durante el procedimiento seguido ante la autoridad nacional de la competencia.

Dando una respuesta afirmativa a dicha pregunta, y en aras del principio de efectividad, el Tribunal de Justicia señaló que un plazo de prescripción de tres años, como del que se trata en el litigio principal, que, por una parte, empieza a correr a partir de la fecha en la que la persona perjudicada tuvo conocimiento de su derecho a indemnización, aunque no se conozca al responsable de la infracción y, por otra parte, no puede suspenderse o interrumpirse en el transcurso de un procedimiento seguido ante la autoridad nacional de la competencia, hace prácticamente imposible o excesivamente difícil el ejercicio del derecho al pleno resarcimiento.

Asimismo, en lo que atañe al principio de equivalencia, resulta que no se ha vulnerado este principio, ya que consta que las reglas nacionales relativas al plazo de prescripción se aplican tanto a las acciones por daños basadas en el derecho de la Unión como a las basadas en el derecho nacional y que su aplicabilidad no depende de si el derecho a reclamar el pleno resarcimiento del perjuicio se deriva de una infracción de las reglas nacionales de competencia o del derecho de la competencia de la Unión.

\section{APROXIMACIÓN DE LEGISLACIONES}

La directiva sobre cláusulas abusivas se opone a que una cláusula de vencimiento anticipado de un contrato de préstamo hipotecario declarada abusiva sea conservada parcialmente mediante la supresión de los elementos que la hacen abusiva, cuando tal supresión equivalga a modificar el contenido de dicha cláusula afectando a su esencia, y, por otra parte, no se opone a que el juez nacional ponga remedio sustituyéndola por la nueva redacción de la disposición legal que inspiró dicha cláusula, aplicable en caso de convenio entre las partes del contrato, siempre que el contrato de préstamo hipotecario en cuestión no pueda subsistir en caso de supresión de la citada cláusula abusiva y la anulación del 
contrato en su conjunto exponga al consumidor a consecuencias especialmente perjudiciales (Sentencia de 26 de marzo de 2019, Abanca Corporación Bancaria y Bankia, C-70/17 y C-179/17, EU:C:2019:250).

Los órganos jurisdiccionales remitentes solicitaban que se dilucidara, fundamentalmente, si los arts. 6 y 7 de la Directiva 93/13/CEE del Consejo, sobre las cláusulas abusivas en los contratos celebrados con consumidores, deben interpretarse en el sentido de que, por una parte, cuando una cláusula de vencimiento anticipado de un contrato de préstamo hipotecario sea declarada abusiva, esta puede, no obstante, conservarse parcialmente mediante la supresión de los elementos que la hacen abusiva y de que, por otra parte, de no ser así, el procedimiento de ejecución hipotecaria iniciado en aplicación de esta cláusula puede en cualquier caso seguir tramitándose aplicando supletoriamente una norma de derecho nacional, en la medida en que la imposibilidad de recurrir a este procedimiento puede ser contraria a los intereses de los consumidores.

En el caso de autos, resultaba de las apreciaciones de los órganos jurisdiccionales remitentes que las cláusulas controvertidas en los litigios principales, pese a estar inspiradas en el art. 693, apdo. 2, de la Ley de Enjuiciamiento Civil, en su versión vigente en la fecha en que se firmaron los contratos de préstamo hipotecario objeto de los litigios principales en los que se incluyeron, deben considerarse abusivas en la medida en que establecen que la entidad financiera puede declarar el vencimiento anticipado del contrato y exigir la devolución del préstamo en caso de que el deudor deje de pagar una mensualidad. En el caso de autos la mera supresión del motivo de vencimiento que convierte en abusivas las cláusulas controvertidas en los litigios principales equivaldría, en definitiva, a modificar el contenido de dichas cláusulas afectando a su esencia. Por lo tanto, no cabe admitir el mantenimiento parcial de dichas cláusulas pues, de otro modo, se menoscabaría directamente el efecto disuasorio.

No obstante, el Tribunal de Justicia ya había declarado que en una situación en la que un contrato concluido entre un profesional y un consumidor no puede subsistir tras la supresión de una cláusula abusiva, el art. 6, apdo. 1, de la Directiva 93/13 no se opone a que el juez nacional, en aplicación de principios del derecho de los contratos, suprima la cláusula abusiva sustituyéndola por una disposición supletoria de derecho nacional en aquellos casos en que la declaración de nulidad de la cláusula abusiva obligue al juez a anular el contrato en su totalidad, quedando expuesto así el consumidor a consecuencias especialmente perjudiciales, que representen para este una penalización.

En el caso de autos, los contratos a los que se refieren los litigios principales tienen por objeto, por un lado, la concesión de préstamos por parte de un banco y, por otro, la constitución de garantías hipotecarias relativas a tales 
préstamos. Las cláusulas controvertidas en los litigios principales, inspiradas en la redacción del art. 693, apdo. 2, de la LEC, en su versión vigente en el momento de la celebración de esos contratos, permiten fundamentalmente a los bancos en cuestión declarar el vencimiento del préstamo y exigir el pago del importe aún no satisfecho cuando deje de abonarse una cuota mensual. Incumbe a los órganos jurisdiccionales remitentes comprobar, con arreglo a las normas de derecho interno y adoptando un enfoque objetivo, si la supresión de esas cláusulas tendría como consecuencia que los contratos de préstamo hipotecario no puedan subsistir.

En tal supuesto, corresponderá a los órganos jurisdiccionales remitentes examinar si la anulación de los contratos de préstamo hipotecario objeto de los litigios principales expondría a los consumidores en cuestión a consecuencias especialmente perjudiciales. A este respecto, resultaba de los autos de remisión que tal anulación podría incidir, en particular, en los cauces procesales de derecho nacional con arreglo a los cuales los bancos pueden reclamar judicialmente el pago de la totalidad del importe del préstamo pendiente de devolución por los consumidores. Así, en caso de anulación de los contratos de préstamo hipotecario objeto de los litigios principales, el cobro de los créditos de los bancos deberá tener lugar a través de un procedimiento de ejecución ordinaria, mientras que seguirá siendo aplicable el procedimiento especial de ejecución hipotecaria en caso de que esos contratos se mantengan sustituyendo la cláusula abusiva por la nueva redacción del art. 693, apdo. 2, de la LEC, que permite declarar el vencimiento anticipado de tales contratos en caso de impago por parte del deudor de, al menos, tres mensualidades. Estos dos procedimientos se distinguen, en particular, por la circunstancia de que el procedimiento especial de ejecución hipotecaria de la vivienda habitual se caracteriza por la posibilidad de que el deudor libere el bien hipotecado antes del cierre de la subasta mediante la consignación de la cantidad debida, por la posibilidad de obtener una reducción parcial de la deuda y por la garantía de que el bien hipotecado no será vendido por un precio inferior al $75 \%$ de su valor de tasación.

Pues bien, tal deterioro de la posición procesal de los consumidores afectados, en caso de recurrirse al procedimiento de ejecución ordinaria en lugar de seguir el cauce del procedimiento especial de ejecución hipotecaria, es pertinente a efectos de apreciar las consecuencias de la anulación de los contratos en cuestión y podría justificar por consiguiente, siempre que exponga a dichos consumidores a consecuencias especialmente perjudiciales, que los órganos jurisdiccionales remitentes sustituyeran las cláusulas abusivas por la versión del citado art. 693, apdo. 2, de la LEC posterior a la celebración de los contratos controvertidos en los litigios principales. Por el contrario, si los órganos jurisdiccionales remitentes llegan a la conclusión de que los 
contratos de préstamo hipotecario en cuestión pueden subsistir sin las cláusulas abusivas controvertidas en los litigios principales, deberían abstenerse de aplicar dichas cláusulas, salvo que el consumidor se oponga a ello, en particular en el caso de que este considere que una ejecución hipotecaria seguida al amparo de tal cláusula le sería más favorable que el cauce del procedimiento de ejecución ordinaria. En efecto, ese contrato debe subsistir, en principio, sin otra modificación que la resultante de la supresión de las cláusulas abusivas, en la medida en que, en virtud de las normas del derecho interno, tal persistencia del contrato sea jurídicamente posible.

\section{UNIÓN ECONÓMICA Y MONETARIA}

El Tribunal de Justicia anula la resolución que suspendía en sus funciones al gobernador del Banco de Letonia debido a que Letonia no aportó pruebas de la falta grave reprochada al gobernador de su banco central (Sentencia de 26 de febrero de 2019, Rimšēvičs y Banco Central Europeo/Letonia, C-202/18 y C-238/18, EU:C:2019:139).

En una sentencia de la Gran Sala, el Tribunal de Justicia trató los recursos interpuestos por el gobernador del Banco de Letonia y el Banco Central Europeo contra la resolución del Estado letón que suspendía al primero de sus funciones. Se trata de los primeros asuntos sometidos al Tribunal de Justicia en virtud de la competencia que le confiere el art. 14.2, párr. segundo, de los Estatutos del Sistema Europeo de Bancos Centrales (SEBC) y del Banco Central Europeo (BCE) para conocer de las decisiones por las que se releve de su mandato a los gobernadores de los bancos centrales nacionales. La atribución de esta competencia al Tribunal de Justicia tiene por objeto, en particular, garantizar la independencia de los gobernadores de los bancos centrales nacionales, que son autoridades nacionales pero desempeñan funciones en el marco del SEBC. Cuando dirigen un banco central de un Estado miembro cuya moneda es el euro, como Letonia, también forman parte del Consejo de Gobierno del BCE.

El 19 de febrero de 2018, la Oficina de Prevención y Lucha contra la Corrupción de Letonia adoptó varias medidas contra el Sr. Ilmārs Rimšēvičs, gobernador del Latvijas Banka (Banco de Letonia), en particular la prohibición de ejercer sus funciones de gobernador del Banco de Letonia, la obligación de abonar una fianza y la prohibición de abandonar el país sin autorización previa. Estas medidas se impusieron provisionalmente al Sr. Rimšēvičs en el marco de una investigación previa relativa a hechos constitutivos de cohecho y de tráfico de influencias que se sospecha cometió el interesado. 
El Tribunal de Justicia declaró ante todo que una prohibición, aun provisional como en el caso de autos, a un gobernador de un banco central nacional de ejercer sus funciones es un relevo del mandato en el sentido del art. 14.2, párr. segundo, de los Estatutos del SEBC y del BCE y, por tanto, cuya legalidad incumbe al Tribunal de Justicia controlar. De este modo, los recursos que se han sido presentados establecen una excepción al reparto general de competencias entre el juez nacional y el juez de la Unión previsto por los tratados, en particular por el art. 263 TFUE.

Por lo que respecta el fondo del asunto, el Tribunal de Justicia señaló que, cuando conoce de un asunto sobre la base del art. 14.2, párr. segundo, de los Estatutos del SEBC y del BCE, no le corresponde sustituir a los tribunales nacionales competentes para pronunciarse sobre la responsabilidad penal del gobernador investigado ni tampoco interferir en la investigación penal preliminar llevada a cabo en su contra por las autoridades administrativas o judiciales competentes. El Tribunal de Justicia consideró que, a efectos de esta investigación, y en particular para impedir que el gobernador afectado la obstruya, puede ser necesario acordar la suspensión temporal de este en sus funciones. En cambio, corresponde al Tribunal de Justicia, en el marco de la competencia que le confiere el art. 14.2, párr. segundo, de los Estatutos del SEBC y del BCE, comprobar que únicamente se decida relevar del mandato a un gobernador de un banco central nacional si existen indicios suficientes de que ha incurrido en una falta grave que pueda justificar tal medida.

El Sr. Rimšěvičs alegó ante el Tribunal de Justicia que no cometió ninguna de las infracciones que se le imputan y considera, al igual que el BCE, que Letonia no aporta la menor prueba de ellas. El Tribunal de Justicia señaló que, durante la fase escrita del procedimiento ante el Tribunal de Justicia, Letonia no aportó ningún principio de prueba de las acusaciones de cohecho que motivaron la adopción de la resolución impugnada. En consecuencia, el Tribunal de Justicia declaró que Letonia no había acreditado que el relevo del mandato del Sr. Rimšěvičs se basara en la existencia de indicios suficientes de que hubiera incurrido en falta grave, en el sentido del art. 14.2, párr. segundo, de los Estatutos del SEBC y del BCE y anuló la resolución impugnada en la medida en que prohíbe al Sr. Rimšēvičs ejercer sus funciones de gobernador del Banco de Letonia.

\section{MEDIO AMBIENTE}

El Tribunal de Justicia desestima el recurso de anulación contra la directiva relativa a la reducción de las emisiones nacionales de determinados 


\section{contaminantes atmosféricos (Sentencia de 13 de marzo de 2019, Polo- nia/Parlamento y Consejo, C-128/17, EU:C:2019:194).}

Polonia sostenía de entrada que el Parlamento y el Consejo incumplieron la obligación de llevar a cabo una evaluación de impacto adecuada de la directiva impugnada antes de su adopción. Para el Tribunal de Justicia, Polonia no podía sostener fundadamente que los datos tenidos en cuenta por el legislador de la Unión para adoptar la directiva impugnada eran incompletos en lo que respecta a la situación particular de Polonia. En lo tocante a la alegación de Polonia según la cual el Parlamento y el Consejo modificaron elementos sustanciales de la propuesta de directiva y, por tanto, habrían debido llevar a cabo una actualización de la evaluación de impacto, en virtud del punto 15 del Acuerdo Interinstitucional sobre la Mejora de la Legislación, el Tribunal de Justicia señala que, en cualquier caso, esa disposición no establece ninguna obligación vinculante para las instituciones interesadas. Únicamente prevé la facultad de proceder a una actualización «cuando lo consideren oportuno y necesario para el procedimiento legislativo».

El Tribunal rechaza también que el Parlamento y el Consejo vulneraran los principios de cooperación leal, de transparencia y de apertura e incumplieran la obligación de motivar los actos jurídicos. El deber de cooperación leal no obliga, en cualquier circunstancia, al legislador de la Unión a aportar, a petición de un Estado miembro, los documentos y la información que supuestamente se hayan omitido o a corregir la información disponible antes de proceder a la adopción de un acto. En efecto, tal interpretación podría impedir a las instituciones ejercer su facultad de apreciación y bloquear el proceso legislativo. Es cierto que el deber de cooperación leal incluye la obligación de asistencia mutua, que implica, en particular, el intercambio de información pertinente entre las instituciones y los Estados miembros en el marco del proceso legislativo. Sin embargo, esta obligación no puede permitir a uno de esos Estados, en caso de desacuerdo sobre la suficiencia, pertinencia y exactitud de los datos disponibles, impugnar por ese mero hecho la legalidad del proceso de toma de decisiones. A este respecto, se desprende de la jurisprudencia del Tribunal que la adopción de un acto legislativo respetando las disposiciones pertinentes del TFUE, pese a la oposición de una minoría de Estados miembros, no puede constituir un incumplimiento de la obligación de cooperación leal que incumbe al Parlamento y al Consejo.

Finalmente, subraya que el legislador de la Unión no está obligado a tener en cuenta la situación particular de un Estado miembro cuando el acto de la Unión de que se trata tiene consecuencias en todos los Estados miembros y, a la vista de los objetivos que persigue, exige que se garantice un equilibrio entre los distintos intereses en juego. Por tanto, la búsqueda de tal 
equilibrio tomando en consideración la situación de todos los Estados miembros de la Unión, y no la situación particular de un solo Estado miembro, no puede, por sí misma, considerarse contraria al principio de proporcionalidad. El hecho de que Polonia forme parte de los Estados miembros que, con el fin de cumplir sus compromisos en el marco de la directiva impugnada, deberán proceder a realizar las inversiones financieras más considerables no significa, en sí mismo, que la directiva imponga una carga desproporcionada al Estado miembro o a las regiones que componen su territorio.

\section{JUSTICIA, LIBERTAD Y SEGURIDAD}

Un solicitante de asilo puede ser trasladado al Estado miembro en principio responsable de la tramitación de su solicitud o que le ha concedido ya protección subsidiaria salvo que las condiciones de vida que previsiblemente encuentran los beneficiarios de protección internacional lo expongan en ese Estado miembro a una situación de privación material extrema, contraria a la prohibición de los tratos inhumanos o degradantes; pero las insuficiencias del sistema social del Estado miembro de que se trate no permiten, por sí solas, llegar a la conclusión de que existe riesgo de que se produzca un trato de esa naturaleza (sentencias de 19 de marzo de 2019, Jawo, C-163/17, EU:C:2019:218 e Ibrahim y otros, C-297/17, C-318/17, C-319/17 y C-438/17, EU:C:2019:219).

Objeto del asunto Jawo era, esencialmente, la cuestión de si la Carta de los Derechos Fundamentales de la Unión Europea se opone a que un solicitante de protección internacional sea trasladado, con arreglo al Reglamento (UE) n. ${ }^{\circ}$ 604/2013 del Parlamento Europeo y del Consejo, por el que se establecen los criterios y mecanismos de determinación del Estado miembro responsable del examen de una solicitud de protección internacional presentada en uno de los Estados miembros por un nacional de un tercer país o un apátrida («Reglamento Dublín III») al Estado miembro en principio responsable de la tramitación de su solicitud si en dicho Estado miembro corre grave riesgo de sufrir un trato inhumano o degradante debido a las condiciones de vida que encontrará previsiblemente como beneficiario de protección internacional (suponiendo que se le conceda tal protección).

El Sr. Jawo, originario de Gambia, presentó una primera solicitud de asilo en Italia, a donde había llegado por mar. Tras continuar su viaje, presentó otra solicitud de asilo en Alemania. Las autoridades alemanas declararon inadmisible esta solicitud y ordenaron el traslado del Sr. Jawo a Italia. Sin embargo, el 
intento de trasladar al Sr. Jawo a Italia fracasó debido a que no se encontraba en el alojamiento comunitario donde se hospedaba.

Ante el Verwaltungsgerichtshof Baden-Württemberg (Tribunal Superior de lo Contencioso-Administrativo de Baden-Wurtemberg, Alemania), el Sr. Jawo alegó que Alemania había pasado a ser el Estado miembro responsable puesto que el plazo de seis meses establecido por el Reglamento Dublín III para trasladarlo al Estado miembro en principio responsable (esto es, Italia) había expirado. Al no haberse dado el Sr. Jawo a la fuga en el momento en que se intentó el traslado, ese plazo no podía ampliarse a un máximo de dieciocho meses. Además, a su parecer, su traslado a Italia sería ilícito porque en ese Estado miembro existen deficiencias sistemáticas en el procedimiento de asilo, en las condiciones de acogida de los solicitantes y en las condiciones de vida de los beneficiarios de protección internacional.

El Verwaltungsgerichtshof Baden-Württemberg solicitaba al Tribunal de Justicia que interpretara el Reglamento Dublín III y la prohibición de los tratos inhumanos o degradantes que figura en la Carta. Hacía referencia al informe de la Organización Suiza de Ayuda a los Refugiados de agosto de 2016, en el que se recogen datos concretos que permiten llegar a la conclusión de que los beneficiarios de protección internacional en Italia corren el riesgo de vivir al margen de la sociedad, sin domicilio fijo y en la indigencia. Según el referido informe, el carácter insuficientemente desarrollado del sistema social del citado Estado miembro se compensa, por lo que respecta a la población italiana, gracias a la solidaridad familiar, que no existe en el caso de los beneficiarios de protección internacional. Dicho informe deja también constancia de la existencia de carencias en los mecanismos de integración en Italia.

Los asuntos Ibrahim y otros se referían a la posibilidad prevista por la Directiva 2013/32/UE del Parlamento Europeo y del Consejo, sobre procedimientos comunes para la concesión o retirada de la protección internacional, de declarar inadmisibles solicitudes de asilo por haberse concedido anteriormente protección subsidiaria en otro Estado miembro. A varios palestinos apátridas que habían residido en Siria se les concedió protección subsidiaria en Bulgaria, mientras que a un nacional ruso, que declara ser checheno, se le concedió tal protección en Polonia. Al haber sido denegadas las nuevas solicitudes de asilo que presentaron posteriormente en Alemania, recurrieron a los órganos jurisdiccionales alemanes.

En los asuntos relativos a los palestinos apátridas, el Bundesverwaltungsgericht (Tribunal Supremo de lo Contencioso-Administrativo, Alemania) pretendía que se dilucidara, en particular, si la facultad de denegar una solicitud por considerarla inadmisible queda sin efecto cuando las condiciones de vida de los beneficiarios de protección subsidiaria en el Estado miembro que concedió tal protección deban ser consideradas trato inhumano o 
degradante, o cuando tales beneficiarios no reciban en dicho Estado miembro prestación alguna de subsistencia, o la que reciban sea netamente inferior a la que se percibe en otros Estados miembros, aun cuando dichas personas no sean tratadas a tal respecto de manera diferente a los nacionales del referido Estado miembro.

En sus dos sentencias el Tribunal de Justicia recuerda que, en el contexto del sistema europeo común de asilo, que se basa en el principio de confianza mutua entre los Estados miembros, debe presumirse que el trato dispensado por un Estado miembro a los solicitantes de protección internacional y a las personas a las que se ha concedido protección subsidiaria es conforme con las exigencias de la Carta, de la Convención de Ginebra y del Convenio Europeo de Derechos Humanos.

No obstante, no cabe excluir que este sistema se enfrente, en la práctica, a graves dificultades de funcionamiento en un Estado miembro determinado, de manera que exista un grave riesgo de que los solicitantes de protección internacional reciban en ese Estado un trato incompatible con sus derechos fundamentales y, en particular, con la prohibición absoluta de los tratos inhumanos o degradantes. Así, cuando el órgano jurisdiccional que conozca de un recurso interpuesto contra una decisión de traslado o contra una resolución que deniegue una nueva solicitud de protección internacional por considerarla inadmisible disponga de datos aportados por el solicitante para acreditar la existencia de un riesgo de trato inhumano o degradante en el otro Estado miembro, dicho órgano jurisdiccional estará obligado a evaluar la existencia de deficiencias, bien sistemáticas o generalizadas, o bien que afecten a ciertos grupos de personas.

No obstante, tales deficiencias solo serán contrarias a la prohibición de los tratos inhumanos o degradantes cuando alcancen un nivel particularmente elevado de gravedad, que dependerá del conjunto de circunstancias del asunto. Así, este umbral se alcanzaría cuando la indiferencia de las autoridades de un Estado miembro tuviese como consecuencia que una persona totalmente dependiente de la ayuda pública se encontrase, al margen de su voluntad y de sus decisiones personales, en una situación de privación material extrema que no le permitiese hacer frente a sus necesidades más elementales, como, entre otras, alimentarse, lavarse y alojarse, y que menoscabase su salud física o mental o la colocase en una situación de degradación incompatible con la dignidad humana.

Una gran precariedad o una notable degradación de las condiciones de vida no rebasa este umbral cuando no implique una privación material extrema que coloque a esa persona en una situación de tal gravedad que pueda equipararse a un trato inhumano o degradante. 
Además, el hecho de que los beneficiarios de protección subsidiaria no reciban, en el Estado miembro que concedió tal protección al solicitante, ninguna prestación de subsistencia o de que la que reciban sea netamente inferior a la que se percibe en otros Estados miembros, sin ser tratados, no obstante, de manera diferente a los nacionales de dicho Estado miembro, solo permite concluir que el solicitante está expuesto en ese Estado a un riesgo real de sufrir un trato inhumano o degradante si tiene como consecuencia que este se encuentre, debido a su especial vulnerabilidad, al margen de su voluntad y de sus decisiones personales, en una situación de privación material extrema.

En cualquier caso, en el contexto del art. 33, apdo. 2, letra a), de la Directiva 2013/32, el mero hecho de que la protección social o las condiciones de vida sean más favorables en el Estado miembro en el que se ha presentado la nueva solicitud de protección internacional que en el Estado miembro en principio responsable o que haya concedido ya la protección subsidiaria no permiten afianzar la conclusión de que la persona afectada se verá expuesta, en caso de ser trasladada a este último Estado miembro, a un riesgo real de sufrir un trato inhumano o degradante.

El Tribunal de Justicia concluye que el derecho de la Unión no se opone a que un solicitante de protección internacional sea trasladado al Estado miembro en principio responsable o a que se deniegue una solicitud de concesión del estatuto de refugiado por considerarla inadmisible debido a que otro Estado miembro ya ha concedido protección subsidiaria al solicitante, salvo que se acredite que el solicitante se encontraría en ese otro Estado miembro en una situación de privación material extrema, al margen de su voluntad y de sus decisiones personales.

En los asuntos Ibrahim y otros, el Tribunal de Justicia añade que el hecho de que el Estado miembro que haya concedido protección subsidiaria a un solicitante de protección internacional deniegue sistemáticamente, sin un examen real, la concesión del estatuto de refugiado no impide que los otros Estados miembros denieguen una nueva solicitud presentada en ellos por el interesado por considerarla inadmisible. En tal caso, corresponde al Estado miembro que concedió la protección subsidiaria reanudar el procedimiento dirigido a la concesión del estatuto de refugiado. En efecto, únicamente si, una vez llevada a cabo una evaluación individual, se aprecia que un solicitante de protección internacional no cumple los requisitos para que se le conceda el estatuto de refugiado, podrá, en su caso, otorgársele la protección subsidiaria.

En el asunto Jawo, el Tribunal de Justicia puntualiza asimismo que un solicitante se da a la "fuga» cuando, con el fin de frustrar su traslado, huye deliberadamente de las autoridades nacionales competentes para efectuarlo. Se presume que ocurre así cuando el traslado no puede efectuarse porque el solicitante ha abandonado el lugar de residencia que le fue asignado, sin haber 
informado de su ausencia a las autoridades nacionales competentes, siempre que dicha persona haya sido informada de sus obligaciones a este respecto, extremo que corresponde verificar al órgano jurisdiccional remitente. El solicitante conserva la posibilidad de demostrar que el hecho de no haber avisado a las referidas autoridades de su ausencia está justificado por razones válidas y no por la intención de huir de tales autoridades.

Además, en un procedimiento contra una decisión de traslado con arreglo al Reglamento Dublín III, el solicitante de protección internacional afectado puede alegar que, en la medida en que no se ha dado a la fuga, el plazo de seis meses para el traslado ha expirado y que, debido a esta circunstancia, el Estado miembro que decidió su traslado se ha convertido en responsable del examen de su solicitud.

Finalmente, el Tribunal de Justicia destaca que, con el fin de ampliar a un máximo de dieciocho meses el plazo de traslado, es suficiente con que el Estado miembro requirente informe al Estado miembro en principio responsable, antes del vencimiento del plazo de traslado de seis meses, del hecho de que la persona interesada se ha dado a la fuga y con que indique, al mismo tiempo, el nuevo plazo de traslado.

Una frontera interior de un Estado miembro en la que se hayan restablecido los controles no puede asimilarse a una frontera exterior en el sentido de la directiva sobre el retorno (Sentencia de 19 de marzo de 2019, Préfet des Pyrénées-Orientales/Abdelaziz Arib, C-444/17, EU:C:2019:220).

El Sr. Arib, de nacionalidad marroquí, fue sometido a un control de identidad en territorio francés, cerca de la frontera terrestre que separa Francia de España, a bordo de un autobús procedente de Marruecos. Previamente había sido objeto de una medida de expulsión del territorio francés. Sospechoso de haber entrado ilegalmente en el territorio francés, fue detenido y el Préfet des Pyrénées-Orientales (Prefecto del departamento de los Pirineos Orientales, Francia) adoptó una resolución por la que se le obligaba a abandonar el territorio francés y se ordenaba su internamiento. La detención preventiva fue anulada en primera instancia, y la cour d'appel confirmó la decisión de primera instancia, por lo que el Prefecto interpuso recurso de casación ante la Cour de cassation (Tribunal de Casación, Francia).

El principio de libre circulación en el interior del espacio Schengen implica la inexistencia de controles de las personas que crucen las fronteras interiores entre los Estados miembros. El control en cuestión se realizó en 2016, durante un periodo en el que se habían restablecido temporalmente en Francia los controles en las fronteras interiores. Al declarar el estado de 
emergencia, Francia había decidido restablecer los controles en las fronteras interiores frente a una amenaza grave para su orden público y su seguridad interior, conforme a las disposiciones del Reglamento (UE) 2016/399 del Parlamento Europeo y del Consejo, por el que se establece un código de normas de la Unión para el cruce de personas por las fronteras (Código de fronteras Schengen).

En este contexto, la Cour de cassation señalaba que la Directiva 2008/115/CE del Parlamento Europeo y del Consejo, relativa a normas y procedimientos comunes en los Estados miembros para el retorno de los nacionales de terceros países en situación irregular (directiva sobre el retorno) permite a los Estados miembros no aplicar a los nacionales de terceros países el procedimiento de retorno que establece cuando a estos se les deniegue la entrada o cuando sean detenidos o interceptados con ocasión del cruce irregular de las fronteras exteriores de un Estado miembro y no hayan obtenido ulteriormente una autorización o derecho de estancia en ese Estado miembro. Dicho órgano jurisdiccional preguntaba al Tribunal de Justicia si una frontera interior en la que se hayan restablecido los controles es asimilable, a los efectos de la citada directiva sobre el retorno, a una frontera exterior y si, en consecuencia, Francia puede decidir no aplicar al Sr. Arib el procedimiento de retorno previsto por la Directiva sobre el retorno.

El Tribunal de Justicia recuerda, en primer lugar, que el Sr. Arib, de nacionalidad marroquí, no fue objeto de una decisión de denegación de entrada en el territorio francés, sino que fue sometido a un control de identidad por las autoridades francesas, en las inmediaciones de la frontera francoespañola, tras haberse restablecido los controles en dicha frontera en virtud del art. 25 del Código de fronteras Schengen, y fue detenido, a raíz de ese control, por ser sospechoso de haber cometido el delito de entrada irregular en el territorio francés. Por lo tanto, según el Tribunal de Justicia, es preciso determinar si un nacional de un tercer país que se encuentra en situación irregular en el territorio de un Estado miembro y que ha sido detenido en las inmediaciones de una frontera interior de dicho Estado miembro está comprendido en la excepción establecida a la aplicación de la directiva sobre el retorno, cuando el Estado miembro de que se trate haya restablecido los controles en esa frontera con arreglo al art. 25 del Código de fronteras Schengen.

El Tribunal de Justicia recuerda que, según su jurisprudencia, la directiva sobre el retorno debe interpretarse en el sentido de que no permite a los Estados miembros excluir de su ámbito de aplicación a los nacionales de terceros países incursos en situación irregular por haber entrado de forma ilegal a través de una frontera interior. Estima además que el restablecimiento por un Estado miembro de controles en sus fronteras interiores no altera esta conclusión. A este respecto, el Tribunal de Justicia considera en particular que, 
a la vista del objetivo perseguido por la directiva sobre el retorno, no procede distinguir el supuesto de un nacional de un tercer país en situación irregular, aprehendido en las inmediaciones de una frontera interior, según que se hayan restablecido o no los controles en dicha frontera.

A continuación, señala que se deduce del Código de fronteras Schengen que una frontera interior en la que un Estado miembro haya restablecido los controles no equivale a una frontera exterior en el sentido del propio código. En efecto, a tenor del Código de fronteras Schengen, los conceptos de «fronteras interiores» $y$ "fronteras exteriores» se excluyen mutuamente. El código se limita a disponer que cuando un Estado miembro restablezca los controles en las fronteras interiores, únicamente se aplicarán las disposiciones de dicho código relativas a las fronteras exteriores que sean pertinentes. El Tribunal de Justicia considera por lo tanto que el propio tenor del Código de fronteras Schengen se opone a que una frontera interior en la que se hayan restablecido los controles se asimile a una frontera exterior.

El Tribunal de Justicia concluye que el art. 2, apdo. 2, letra a), de la Directiva 2008/115/CE, en relación con el art. 32 del Código de fronteras Schengen, no se aplica a la situación de un nacional de un tercer país, detenido en las inmediaciones de una frontera interior y en situación irregular en el territorio de un Estado miembro, aun cuando ese Estado miembro haya restablecido, en virtud del art. 25 de dicho código, los controles en tal frontera, debido a una amenaza grave para el orden público o la seguridad interior del citado Estado miembro.

Un Estado miembro que ha notificado su intención de retirarse de la Unión de conformidad con el art. 50 TUE sigue siendo el Estado responsable en el sentido del Reglamento Dublín III, y corresponde a cada Estado miembro determinar las circunstancias en que desea hacer uso de su facultad discrecional y aceptar examinar él mismo una solicitud de protección internacional de la que no es responsable (Sentencia de 23 de enero de 2019, M.A., S.A., A.Z. / International Protection Appeals Tribunal y otros, C-661/17, EU:C:2019:53).

El 10 de enero de 2017, el International Protection Appeals Tribunal [Tribunal de Apelación en materia de Protección Internacional (IPAT), Irlanda] confirmó una decisión del Comisionado irlandés para los Refugiados en la que se recomendaba el traslado de S. A. y M. A. y del hijo de ambos, A. Z., al Reino Unido. El Comisionado había considerado que el Reino Unido era el país responsable de hacerse cargo de las solicitudes de asilo presentadas por S. A. y M. A. sobre la base del Reglamento (UE) n. ${ }^{\circ}$ 604/2013 del Parlamento Europeo y del Consejo, por el que se establecen los criterios y mecanismos 
de determinación del Estado miembro responsable del examen de una solicitud de protección internacional presentada en uno de los Estados miembros por un nacional de un tercer país o un apátrida (Reglamento Dublín III).

El IPAT consideró que carecía de competencia para ejercer la facultad que confiere la cláusula discrecional establecida en el art. 17, apdo. 1, del Reglamento Dublín III, según la cual cualquier Estado miembro puede decidir examinar una solicitud de protección internacional que le sea presentada, aun cuando este examen no le incumba en virtud de los criterios de determinación del Estado miembro responsable. La High Court (Tribunal Superior, Irlanda), que conoce del recurso interpuesto contra la resolución del IPAT, consideró que, para resolver el litigio del que conoce, era necesario determinar previamente las implicaciones que puede tener para el sistema de Dublín el proceso de retirada del Reino Unido de la Unión.

El Tribunal de Justicia comienza recordando que la notificación por un Estado miembro de su intención de retirarse de la Unión de conformidad con el art. 50 TUE no produce el efecto de suspender la aplicación del derecho de la Unión en ese Estado miembro y que, por consiguiente, ese derecho sigue plenamente en vigor en dicho Estado hasta la retirada efectiva de este de la Unión.

Añade que se desprende claramente del tenor de la cláusula discrecional establecida en el Reglamento Dublín III que dicha cláusula es de naturaleza facultativa y que la facultad que confiere no está sujeta a ningún requisito particular. Pretende permitir a cada Estado miembro decidir de forma soberana, en función de consideraciones políticas, humanitarias o prácticas, si acepta examinar una solicitud de protección internacional a pesar de no ser responsable con arreglo a los criterios definidos en dicho reglamento. Esto es coherente tanto con la finalidad de esa cláusula, a saber, salvaguardar las prerrogativas de los Estados miembros en el ejercicio del derecho a conceder protección internacional, como con la reiterada jurisprudencia del Tribunal de Justicia según la cual las disposiciones facultativas otorgan un amplio margen de apreciación a los Estados miembros.

El Tribunal de Justicia considera que el hecho de que un Estado miembro — en el presente asunto, el Reino Unido_- designado como responsable a efectos del Reglamento Dublín III, haya notificado su intención de retirarse de la Unión de conformidad con el art. 50 TUE no obliga al Estado miembro encargado de la determinación —en el presente asunto, Irlanda- a examinar él mismo, con arreglo a la cláusula discrecional, la solicitud de protección internacional.

Además, el Tribunal de Justicia examina si el Reglamento Dublín III debe interpretarse en el sentido de que exige que la determinación del Estado miembro responsable con arreglo a los criterios definidos en ese reglamento 
y el ejercicio de la cláusula discrecional establecida en él sean competencia de la misma autoridad nacional. A este respecto, el Tribunal de Justicia apunta que el Reglamento Dublín III no contiene ninguna disposición que indique qué autoridad está facultada para adoptar una decisión con arreglo a los criterios definidos en dicho reglamento relativos a la determinación del Estado miembro responsable o con arreglo a la cláusula discrecional ni tampoco precisa si un Estado miembro debe encomendar la tarea de aplicar tales criterios y la de ejercer esa cláusula discrecional a la misma autoridad. En cambio, el reglamento sí establece que cada Estado miembro notificará sin demora a la Comisión las autoridades específicas encargadas del cumplimiento de las obligaciones derivadas del propio reglamento y toda modificación de tales autoridades.

El Tribunal de Justicia concluye que corresponde a los Estados miembros decidir qué autoridades nacionales son competentes para aplicar el Reglamento Dublín III. Añade que un Estado miembro es libre de encomendar a autoridades distintas la tarea de aplicar los criterios definidos en ese reglamento relativos a la determinación del Estado miembro responsable y la de ejercer la cláusula discrecional de dicho reglamento.

Por otra parte, el art. 6, apdo. 1, del Reglamento Dublín III no impone a un Estado miembro que no es responsable, en virtud de los criterios establecidos en ese reglamento, de examinar una solicitud de protección internacional que tenga en cuenta el interés superior del niño y que examine él mismo esa solicitud, con arreglo a la cláusula discrecional de dicho reglamento.

Además, el Tribunal de Justicia considera que el art. 27, apdo. 1, del Reglamento Dublín III no exige que exista un recurso contra la decisión de no hacer uso de la cláusula discrecional, sabiendo que dicha decisión podrá ser impugnada con ocasión de un recurso contra la decisión de traslado. Por último, declara que, a falta de prueba en contrario, el art. 20, apdo. 3, del Reglamento Dublín III establece una presunción según la cual redunda en el interés superior del niño tratar la situación de este de forma indisociable de la de sus padres.

El art. 6 de la Carta de los Derechos Fundamentales de la Unión Europea se opone a un criterio jurisprudencial nacional que permite el mantenimiento de la detención de la persona reclamada una vez transcurrido el plazo de noventa días, cuando este criterio jurisprudencial no garantice la conformidad de dicha disposición nacional con la decisión marco sobre la orden de detención europea, y presente divergencias que puedan traducirse en duraciones diferentes del mantenimiento en situación de privación de libertad (Sentencia de 12 de febrero de 2019, TC, C-492/18 PPU, EU:C:2019:108). 
La petición de decisión prejudicial tenía por objeto la interpretación del art. 6 de la Carta de los Derechos Fundamentales de la Unión Europea, en el contexto de la ejecución, en los Países Bajos, de una orden de detención europea emitida contra TC por las autoridades competentes del Reino Unido.

La cuestión prejudicial planteada se basaba en la premisa de que la obligación de suspender la medida de privación de libertad de la persona reclamada en cualquier caso cuando transcurre un plazo de noventa días desde su detención, tal como viene impuesta por el derecho nacional (art. 22, apdo. 4, de la OLW), era incompatible con la Decisión Marco 2002/584 JAI del Consejo, relativa a la orden de detención europea y a los procedimientos de entrega entre Estados miembros. Diversos órganos jurisdiccionales habían desarrollado criterios jurisprudenciales tendentes a restablecer la conformidad del ordenamiento jurídico nacional con esta decisión Marco.

El Tribunal recuerda que con arreglo al art. 12 de la decisión marco, la autoridad judicial de ejecución decidirá de conformidad con el derecho del Estado miembro de ejecución si debe permanecer privada de libertad una persona detenida en virtud de una orden de detención europea. Ese artículo precisa además que la libertad provisional de esta persona podrá ser acordada en todo momento, de conformidad con el derecho de ese Estado, siempre que la autoridad competente de dicho Estado tome todas las medidas que considere necesarias para evitar la fuga de esa persona.

Por el contrario, señala que este artículo no dispone, de forma general, que el mantenimiento de la detención de la persona reclamada únicamente sea factible con unos límites temporales precisos ni, en particular, que este quede excluido una vez expirados los plazos establecidos en el art. 17 de la misma decisión marco. Del mismo modo, si bien el art. 12 de la Decisión Marco 2002/584 admite la posibilidad, con ciertas condiciones, de que se ponga en libertad provisional a la persona detenida sobre la base de una orden de detención europea, ni esta disposición ni ninguna otra de esa norma disponen que, tras la expiración de los plazos establecidos en el art. 17 de la misma, la autoridad judicial de ejecución deba proceder a tal puesta en libertad o, a fortiori, a una liberación pura y simple de dicha persona. En efecto, dado que el procedimiento de ejecución de la orden de detención europea debe proseguirse en todo caso una vez expirados los plazos establecidos en el art. 17 de la Decisión Marco 2002/584, una obligación general e incondicional de puesta en libertad provisional o, a fortiori, de liberación pura y simple del detenido tras la expiración de esos plazos o cuando la duración total del periodo de detención de la persona reclamada supere dichos plazos podría limitar la eficacia del sistema de entrega instaurado por la decisión marco y, por lo tanto, obstaculizar la consecución de los objetivos perseguidos por esta. 
Por consiguiente, la obligación impuesta por el art. 22, apdo. 4, de la OLW de suspender en cualquier caso la medida de detención impuesta a la persona reclamada con vistas a su entrega una vez que ha transcurrido un plazo de noventa días desde su detención es incompatible con las disposiciones de la Decisión Marco 2002/584, tal como por otra parte observó el órgano jurisdiccional remitente en su petición de decisión prejudicial.

Señala que la interpretación de dicha disposición nacional llevada a cabo por el órgano jurisdiccional remitente no parece que permita poner remedio a esta incompatibilidad en cualquier circunstancia.

Por ello, concluye que el art. 6 de la Carta se opone a un criterio jurisprudencial nacional que permite el mantenimiento de la detención de la persona reclamada una vez transcurrido ese plazo de noventa días, basándose en una interpretación de esta disposición nacional según la cual este plazo queda suspendido cuando la autoridad judicial de ejecución decide bien plantear una petición de decisión prejudicial al Tribunal de Justicia, bien esperar la respuesta a una petición de decisión prejudicial formulada por otra autoridad judicial de ejecución, o bien incluso posponer la resolución en cuanto a la entrega por la razón de que podría existir, en el Estado miembro de emisión, un riesgo real de condiciones de detención inhumanas o degradantes, cuando este criterio jurisprudencial no garantice la conformidad de dicha disposición nacional con la Decisión Marco 2002/584 y presente divergencias que puedan traducirse en duraciones diferentes del mantenimiento en situación de privación de libertad.

En efecto, el art. 12 de la citada decisión marco debe interpretarse con arreglo al art. 6 de la Carta, que dispone que toda persona tiene derecho a la libertad y a la seguridad. Dado que el mantenimiento de la detención de una persona reclamada una vez superado un plazo de noventa días lesiona gravemente su derecho a la libertad, está supeditado a que se respeten unas garantías estrictas, a saber, la existencia de una base legal que lo justifique, debiendo observar tal base legal las exigencias de claridad, de previsibilidad y de accesibilidad para evitar cualquier riesgo de arbitrariedad.

En el caso de autos, era claro y previsible, desde una fecha muy anterior al inicio del procedimiento principal, que tanto el órgano jurisdiccional remitente como el Tribunal de Apelación de Ámsterdam estaban obligados a hacer todo cuanto estuviera dentro del ámbito de sus competencias para garantizar la plena efectividad de la Decisión Marco 2002/584, dando al art. 22, apdo. 4 , de la OLW y a la obligación de ordenar la puesta en libertad provisional establecida por esta disposición una interpretación conforme con la finalidad perseguida por esta decisión marco. No obstante, las interpretaciones de esta disposición nacional realizadas por el órgano jurisdiccional remitente y por el Tribunal de Apelación de Ámsterdam para garantizar su conformidad con 
la citada decisión marco no respetan por completo las exigencias de esta. En particular, la interpretación seguida por el órgano jurisdiccional remitente no ha permitido garantizar, en el caso de autos, la conformidad del art. 22, apdo. 4, de la OLW con la Decisión Marco 2002/584.

En un asunto como el que es objeto del litigio principal, personas detenidas en los Países Bajos a efectos de su entrega, como TC, se encuentran tanto ante disposiciones de derecho nacional - concretamente el art. 22, apdo. 4, de la OLW-y del derecho de la Unión —esto es, los arts. 12 y 17 de la Decisión Marco 2002/584 - incompatibles entre sí, como ante una divergencia de criterios jurisprudenciales nacionales en relación con esta disposición de derecho nacional dirigidos a interpretarla de modo conforme con el derecho de la Unión. En estas circunstancias, declara que la divergencia existente entre la interpretación hecha por el órgano jurisdiccional remitente y el criterio jurisprudencial del Tribunal de Apelación de Ámsterdam no permite determinar con la claridad y la previsibilidad exigidas por la jurisprudencia del Tribunal de Justicia la duración del mantenimiento de la detención, en los Países bajos, de una persona reclamada en el marco de una orden de detención europea emitida contra ella.

\section{RELACIONES EXTERIORES}

El mecanismo de solución de diferencias entre inversores y Estados previsto por el Acuerdo de Libre Comercio entre la Unión Europea y Canadá (CETA) es compatible con el derecho de la Unión (Dictamen de 30 de abril de 2019, 1/17, EU:C:2019:341).

El 30 de octubre de 2016, Canadá, por un lado, y la Unión Europea y sus Estados miembros, por otro, firmaron un acuerdo de libre comercio: el Comprehensive Economic and Trade Agreement (en lo sucesivo, CETA). La sección del CETA dedicada a las inversiones tiene por objeto, en particular, establecer un mecanismo de solución de diferencias entre inversores y Estados. De este modo se proyecta establecer un sistema de tribunales de inversiones como mecanismo de solución de diferencias en materia de inversiones entre inversores y Estados (en lo sucesivo, mecanismo SDIE), conocido igualmente por el acrónimo ISDS (Investor-State Dispute Settlement).

Bélgica solicitó un dictamen al Tribunal de Justicia en relación con la compatibilidad de este mecanismo de solución de diferencias con el derecho primario de la Unión. Esencialmente, Bélgica expresaba sus dudas acerca de los efectos de este mecanismo sobre la competencia exclusiva del Tribunal de Justicia para interpretar con carácter definitivo el derecho de la Unión y, 
por consiguiente, sobre la autonomía del ordenamiento jurídico de la Unión, en cuanto a su compatibilidad con el principio general de igualdad de trato y con la exigencia de efectividad del derecho de la Unión, así como en lo que se refiere al respeto por parte de dicho mecanismo del derecho a un juez independiente e imparcial.

En su dictamen el Tribunal de Justicia recuerda, en primer lugar, que un acuerdo internacional que contemple la creación de un órgano jurisdiccional encargado de interpretar sus disposiciones y cuyas decisiones vinculen a la Unión es, en principio, compatible con el derecho de la Unión. Por otro lado, un acuerdo internacional de esta índole puede incidir en las competencias de las instituciones de la Unión siempre que, no obstante, se cumplan los requisitos esenciales para preservar la naturaleza de esas competencias y, por lo tanto, no se vulnere la autonomía del ordenamiento jurídico de la Unión, que se basa en un marco constitucional propio. En este marco se incluyen los valores fundacionales de la Unión: el respeto de la dignidad humana, la libertad, la democracia, la igualdad, el Estado de derecho y el respeto de los derechos humanos.

Tras recapitular sobre su jurisprudencia, el Tribunal de Justicia considera de entrada que para comprobar la compatibilidad del mecanismo SDIE previsto con la autonomía del ordenamiento jurídico de la Unión es necesario cerciorarse de que el capítulo ocho, sección F, del CETA no atribuya a los tribunales cuya creación se prevé ninguna competencia de interpretación o aplicación del derecho de la Unión distinta de la de interpretar y aplicar las disposiciones de dicho acuerdo a la luz de las normas y principios del derecho internacional aplicables entre las partes, y dicho capítulo ocho, sección F, no configure las competencias de dichos tribunales de modo que estos, aun sin llevar a cabo una interpretación o aplicación de las normas del derecho de la Unión que no sean las de dicho acuerdo, puedan dictar laudos que tengan como efecto impedir que las instituciones de la Unión actúen conforme al marco constitucional de esta.

Sobre la falta de competencia para interpretar y aplicar normas del derecho de la Unión que no sean las disposiciones del CETA, el Tribunal recuerda que la competencia de interpretación y aplicación atribuida al Tribunal del CETA se limita a las disposiciones del CETA y que tal interpretación y aplicación deben realizarse de conformidad con las normas y principios del derecho internacional aplicables entre las partes. En ello se distingue el capítulo ocho, sección F, del CETA del proyecto de acuerdo por el que se crea un Sistema Unificado de Resolución de Litigios sobre Patentes, declarado incompatible con el derecho de la Unión en el Dictamen 1/09. En efecto, el «Derecho aplicable» en el marco de dicho proyecto, definido en su art. 14 bis, incluía en particular «la legislación comunitaria directamente aplicable, en 
particular el reglamento [...] del Consejo sobre la patente comunitaria, y la legislación nacional [...] mediante la que se aplica la legislación comunitaria». El Tribunal de Justicia dedujo de lo anterior, en el dictamen, que el órgano jurisdiccional de patentes cuya creación se preveía estaría llamado a interpretar y aplicar no solo las disposiciones de ese acuerdo, sino también el futuro reglamento sobre la patente comunitaria y otros instrumentos del derecho de la Unión, en particular los reglamentos y directivas con los que el citado reglamento debería, en su caso, ser conjuntamente interpretado.

El capítulo ocho, sección F, del CETA se diferencia también del acuerdo de inversión controvertido en el asunto en el que se dictó la sentencia Achmea (C-284/16), puesto que, como indicó el Tribunal de Justicia en los apdos. 42, 55 y 56 de dicha sentencia ese acuerdo establecía un tribunal que habría de resolver litigios que pudieran tener relación con la interpretación o aplicación del derecho de la Unión. Dicha sentencia se refería, además, a un acuerdo entre Estados miembros. Pues bien, la cuestión de la compatibilidad con el derecho de la Unión del establecimiento o mantenimiento de un tribunal de inversiones mediante un acuerdo de este tipo difiere de la cuestión de la compatibilidad con dicho derecho del establecimiento de un tribunal de inversiones mediante un acuerdo entre la Unión y un Estado tercero. En efecto, los Estados miembros están obligados a observar el principio de confianza mutua en todos los ámbitos comprendidos en el derecho de la Unión. Este principio exige a cada uno de los Estados miembros, salvo en circunstancias excepcionales, que considere que todos los demás Estados miembros respetan el derecho de la Unión, incluidos los derechos fundamentales, como el derecho a la tutela judicial efectiva ante un tribunal independiente enunciado en el art. 47 de la Carta. Pues bien, ese principio de confianza mutua, en particular en cuanto al derecho a la tutela judicial efectiva ante un tribunal independiente, no se aplica en las relaciones entre la Unión y un Estado tercero.

Esta conclusión, no queda desvirtuada por el art. 8.31, apdo. 2, del CETA, que establece que, «al determinar la compatibilidad de una medida con el presente Acuerdo, el tribunal podrá tener en cuenta, en su caso, el Derecho interno de una Parte como un elemento de hecho» y enuncia que, «al hacerlo, el tribunal seguirá la interpretación predominante dada al Derecho interno por los órganos jurisdiccionales o las autoridades de dicha Parte», añadiendo que «cualquier sentido que el tribunal haya dado al Derecho interno no será vinculante para los órganos jurisdiccionales o las autoridades de dicha Parte». En efecto, estas precisiones solo tienen por objeto reflejar el hecho de que el Tribunal del CETA, cuando deba examinar la conformidad con el CETA de la medida impugnada por el inversor que ha sido adoptada por el Estado de acogida de la inversión o por la Unión, habrá de proceder necesariamente a un examen del alcance de dicha medida sobre la base de la información y 
las alegaciones que presenten ese inversor, ese Estado o la Unión. En su caso, ese examen podrá requerir que se tome en consideración el derecho interno de la parte demandada. Pues bien, como indica inequívocamente el art. 8.31, apdo. 2, del CETA, dicho examen no podrá equipararse a una interpretación de dicho derecho por el Tribunal del CETA, sino que consistirá, por el contrario, en una toma en consideración de ese derecho como elemento de hecho. En este contexto, dicho Tribunal estará obligado a seguir la interpretación dominante de ese derecho realizada por los órganos jurisdiccionales y las autoridades de la mencionada parte, y dichos órganos jurisdiccionales y autoridades no estarán vinculados, por lo demás, por el sentido que dé a ese derecho interno el mencionado tribunal.

La falta de competencia para interpretar normas del derecho de la Unión que no sean las disposiciones del CETA también se refleja en el art. 8.21 de dicho acuerdo, que atribuye a la Unión, y no al Tribunal del CETA, la facultad de determinar, cuando un inversor canadiense pretenda impugnar medidas adoptadas por un Estado miembro o por la Unión, si, habida cuenta de las normas sobre el reparto de competencias entre la Unión y sus Estados miembros, la diferencia debe dirigirse contra ese Estado miembro o contra la Unión. De este modo se preserva la competencia exclusiva del Tribunal de Justicia para resolver sobre el reparto de competencias entre la Unión y sus Estados miembros.

El Tribunal de Apelación del CETA tampoco estará obligado a interpretar o aplicar normas del derecho de la Unión que no sean las disposiciones del CETA. Por lo demás, puesto que el Tribunal y el Tribunal de Apelación del CETA no pertenecen al sistema jurisdiccional de la Unión, y su competencia de interpretación se limita a las disposiciones del CETA conforme a las normas y principios del derecho internacional aplicables entre las partes, es coherente que el CETA no prevea ningún procedimiento de intervención previa que faculte u obligue a dicho Tribunal o a dicho Tribunal de Apelación a dirigirse al Tribunal de Justicia con carácter prejudicial.

Por ello concluye que el capítulo ocho, sección F, del CETA no atribuye a los tribunales cuya creación prevé ninguna competencia de interpretación o de aplicación del derecho de la Unión que no sea la relativa a las disposiciones de dicho acuerdo.

Para examinar la falta de efecto en el funcionamiento de las instituciones de la Unión conforme al marco constitucional de esta señala, en primer lugar, que la definición del concepto de «inversión», contenida en el art. 8.1 del CETA, es especialmente extensa y permite que los tribunales previstos conozcan de un amplio abanico de diferencias. Las presentadas contra la Unión o un Estado miembro podrán referirse, sin perjuicio de las excepciones concretas mencionadas en el CETA, a medidas en cualquier ámbito 
que concierna, en la Unión, a la explotación de empresas y a la utilización de bienes muebles e inmuebles, títulos financieros, derechos de propiedad intelectual, créditos y cualquier otro tipo de inversión.

En segundo lugar, indica que, a pesar del art. 8.21 del CETA, que faculta a la Unión para determinar, en caso de demanda presentada ante el Tribunal por un inversor canadiense, si será ella quien asuma el papel de demandado o si dejará esta tarea al Estado miembro de acogida de la inversión, la Unión no podrá oponerse, cuando la medida impugnada haya sido adoptada por ella, a que dicha medida sea examinada por este Tribunal. En efecto, como se desprende de las normas procesales establecidas en el CETA, en particular del art. 8.25, apdo. 1, de este, se presume que el demandado, ya sea el Estado miembro de acogida de la inversión o la propia Unión, acepta que la diferencia sea resuelta por dicho Tribunal.

En tercer lugar, señala que puesto que la definición del término «medida» establecida en dicho art. 1.1 incluye «una ley, un reglamento, una norma, un procedimiento, una decisión, una acción administrativa, un requisito, prácticas o cualquier otro tipo de medida adoptada por una Parte», las diferencias contra la Unión podrán referirse a todo tipo de acto o práctica de esta, siempre que, conforme al art. 8.2 del CETA, interpretado en relación con el capítulo ocho, secciones $\mathrm{C}, \mathrm{D}$ y F, de dicho acuerdo, el acto o la práctica de que se trate «se refiera» a una «inversión cubierta» en el sentido del art. 8.1 del mismo acuerdo o al «inversor de la otra Parte» por lo que se refiere a la inversión cubierta. Por tanto, si bien se deriva del CETA que la diferencia debe tener por objeto una medida que se refiera al demandante o a su inversión cubierta, dicho acuerdo no excluye que esa medida tenga un alcance general o ejecute un acto de carácter general.

Aunque el Tribunal del CETA no puede anular la medida impugnada o exigir la adecuación del derecho interno de la parte afectada con el CETA ni infligir una sanción a la parte demandada, sí puede, por el contrario, cuando compruebe que esa medida infringe alguna disposición del capítulo ocho, sección C o D, del CETA, condenar, en virtud del citado art. 8.39, apdo. 1, letra a), a la parte demandada a abonar al inversor demandante una cantidad que compense los daños sufridos por este debido a dicha infracción y que incluya el interés aplicable. Puesto que el art. 8.41, apdo. 2, del CETA precisa que «una parte en la diferencia deberá reconocer y cumplir un laudo sin demora alguna», la Unión deberá abonar esa cantidad cuando sea condenada mediante un laudo definitivo del Tribunal del CETA o, según los requisitos establecidos en el art. 8.28, apdo. 9, de dicho acuerdo, del Tribunal de Apelación del CETA.

A este respecto, observa que la competencia, establecida en el art, 8.39, apdo. 1, letra a), del CETA, de los tribunales cuya creación se prevé para 
conceder una indemnización a un inversor privado es un aspecto del mecanismo SDIE instaurado por ese acuerdo que distingue ese mecanismo del sistema, en vigor en la Organización Mundial del Comercio (OMC), de solución de diferencias entre las partes contratantes de la $\mathrm{OMC}$, dado que ese sistema está parcialmente basado en las negociaciones de estas partes contratantes e incluye varias opciones para la ejecución de los laudos.

Las características de la competencia del Tribunal y del Tribunal de Apelación del CETA son, ciertamente, coherentes con la protección de los inversores extranjeros contemplada en ese acuerdo. No obstante, y sin perjuicio de los supuestos en que las partes hayan convenido, en el marco del CETA, aproximar sus legislaciones, la competencia de esos tribunales vulneraría la autonomía del ordenamiento jurídico de la Unión si estuviera concebida de modo que estos pudieran, al apreciar las restricciones a la libertad de empresa mencionadas en una demanda, cuestionar el nivel de protección del interés público que haya motivado el establecimiento por la Unión de esas restricciones respecto al conjunto de operadores que invierten en el sector comercial o industrial de que se trate del mercado interior, en vez de limitarse a comprobar si el trato dado a un inversor o a una inversión cubierta adolece de alguno de los vicios mencionados en el capítulo ocho, sección $\mathrm{C}$ o D, del CETA. En efecto, si el Tribunal y el Tribunal de Apelación del CETA fueran competentes para dictar laudos en los que se declare incompatible con el CETA el trato a un inversor canadiense debido al nivel de protección de un interés público fijado por las instituciones de la Unión, cabría la posibilidad de que esta renunciara a lograr ese nivel de protección para no verse obligada de modo reiterado por el Tribunal del CETA a abonar indemnizaciones al inversor demandante.

Si la Unión celebrara un acuerdo internacional que pudiera tener como consecuencia que ella - o un Estado miembro en el marco de la ejecución del derecho de la Unión - tuviera que modificar o retirar una normativa debido a la apreciación realizada por un tribunal que no pertenece a su sistema jurisdiccional acerca del nivel de protección de un interés público establecido, conforme al marco constitucional de la Unión, por las instituciones de esta, tal acuerdo comprometería la capacidad de la Unión de actuar de manera autónoma en su propio marco constitucional. A este respecto, señala que el legislador de la Unión adopta la normativa de esta al término de un procedimiento democrático definido en los Tratados UE y FUE y se considera que esta normativa, en virtud de los principios de atribución de competencias, subsidiariedad y proporcionalidad establecidos en el art. 5 TUE, es tanto apropiada como necesaria para lograr un objetivo legítimo de la Unión. Conforme al artículo 19 TUE, corresponde al juez de la Unión garantizar, en particular, el control de la conformidad del nivel de protección de los intereses públicos 
fijado por tal normativa con los Tratados UE y FUE, la Carta y los principios generales del derecho de la Unión.

Por lo que se refiere a la competencia de los tribunales cuya creación se prevé para declarar la existencia de infracciones a las obligaciones establecidas en la sección C del capítulo ocho del CETA, el art. 28.3, apdo. 2, de dicho acuerdo prescribe que las disposiciones de esa sección $C$ no pueden interpretarse de modo que impidan que cualquiera de las partes adopte o haga cumplir las medidas necesarias para proteger la seguridad pública o la moral pública, para mantener el orden público, para proteger la salud y la vida de las personas y de los animales o para preservar los vegetales, con la sola condición de que tales medidas no se apliquen de forma que constituyan un medio de discriminación arbitrario o injustificable entre las partes cuando existan condiciones similares, o una restricción encubierta del comercio entre las partes. Por ello el Tribunal del CETA no será competente para declarar que el nivel de protección de un interés público establecido por las medidas de la Unión es incompatible con el CETA ni para condenar, sobre esta base, a la Unión al pago de indemnizaciones.

Del mismo modo, el art. 8.9, apdo. 1, del acuerdo recuerda expresamente el derecho de la partes «a regular en sus territorios para alcanzar objetivos políticos legítimos, como la protección de la salud pública, la seguridad, el medio ambiente, la moral pública, la protección social o de los consumidores, o la promoción y la protección de la diversidad cultural». Por otro lado, el art. 8.9, apdo. 2, de dicho acuerdo prevé que, "para mayor seguridad, el mero hecho de que una Parte regule, incluso mediante una modificación de su legislación, de tal forma que afecte negativamente a las inversiones o no satisfaga las expectativas de un inversor, incluidas sus expectativas de beneficios, no constituye un incumplimiento de ninguna de las obligaciones establecidas en la presente sección».

De la lectura conjunta de esas disposiciones se deriva que la facultad de apreciación del Tribunal y del Tribunal de Apelación del CETA no les permite cuestionar el nivel de protección de un interés público definido por la Unión a raíz de un procedimiento democrático.

Añade que la competencia del Tribunal del CETA para declarar la existencia de infracciones a la obligación, establecida en el art. 8.10 del CETA, de brindar un "trato justo y equitativo» a las inversiones cubiertas está específicamente delimitada, puesto que el apdo. 2 de ese artículo enumera con carácter exhaustivo los supuestos en los que puede llevarse a cabo esta declaración. A este respecto, las partes se han centrado en especial en las situaciones de trato abusivo, trato arbitrario manifiesto y discriminación específica, lo que muestra, una vez más, que el nivel exigido de protección de un interés público, tal como se concreta tras un procedimiento democrático, no está 
comprendido en la competencia de que disponen los tribunales previstos para comprobar si un trato dado por una parte a un inversor o a una inversión cubierta es «justo y equitativo».

Por tanto, del conjunto de esas cláusulas contenidas en el CETA se desprende que, al delimitar expresamente el alcance del capítulo ocho, secciones $\mathrm{C}$ y $\mathrm{D}$, de ese acuerdo, que son las únicas secciones que pueden invocarse ante los tribunales previstos por la sección $\mathrm{F}$ de dicho capítulo, las partes se han ocupado de excluir que esos tribunales tengan competencia para cuestionar las opciones elegidas democráticamente por una parte en materia, en particular, de nivel de protección del orden público, de la seguridad pública, de la moral pública, de la salud y la vida de las personas y de los animales, de la seguridad alimentaria, de los vegetales, del medio ambiente, del bienestar en el trabajo, de la seguridad de los productos, de los consumidores o incluso de los derechos fundamentales.

En cuanto a la compatibilidad del mecanismo previsto con el principio general de igualdad de trato, el Tribunal de Justicia señala que, si bien el CETA tiene como finalidad proporcionar a los inversores canadienses que invierten en la Unión una vía específica de recurso contra las medidas de la Unión, su situación no es comparable con la de los inversores de los Estados miembros que invierten en la Unión. El Tribunal de Justicia afirma asimismo que el CETA no vulnera la efectividad del derecho de la Unión por el único motivo de que un laudo dictado por el Tribunal creado por este acuerdo pueda tener como consecuencia, en circunstancias excepcionales, que se neutralice una multa por infracción del derecho de la competencia impuesta por la Comisión o por una autoridad de la competencia de un Estado miembro. En efecto, el propio derecho de la Unión permite anular una multa cuando esta adolece de un vicio similar al que podría declarar el Tribunal del CETA.

En lo que respecta a la compatibilidad del mecanismo de solución de diferencias con el derecho a un juez independiente, el Tribunal de Justicia indica que la finalidad del acuerdo es hacer que el Tribunal del CETA sea accesible a cualquier empresa o persona física canadiense que invierta en la Unión y a cualquier empresa o persona física de un Estado miembro de la Unión que invierta en Canadá. Sin embargo, ante la falta de un régimen que garantice la accesibilidad al Tribunal y al Tribunal de Apelación, desde un punto de vista económico, de las personas físicas y de las pequeñas y medianas empresas (PME), en la práctica el mecanismo podría resultar exclusivamente accesible a los inversores que dispongan de elevados recursos financieros. Pues bien, el Tribunal de Justicia considera que los compromisos adoptados por la Comisión y el Consejo para garantizar que las PME puedan acceder a los tribunales proyectados bastan para concluir, en el marco del presente procedimiento de dictamen, que el CETA es compatible con la exigencia de accesibilidad. En 
efecto, la aprobación del acuerdo por la Unión está condicionada por esos compromisos.

Por último, el Tribunal de Justicia concluye que el Acuerdo CETA contiene garantías suficientes para asegurar la independencia de los miembros de los tribunales proyectados. 